NBER WORKING PAPER SERIES

PUBLIC DEBT THROUGH THE AGES

\author{
Barry Eichengreen \\ Asmaa El-Ganainy \\ Rui Esteves \\ Kris James Mitchener \\ Working Paper 25494 \\ http://www.nber.org/papers/w25494
}

\author{
NATIONAL BUREAU OF ECONOMIC RESEARCH \\ 1050 Massachusetts Avenue \\ Cambridge, MA 02138 \\ January 2019
}

NBER working papers are circulated for discussion and comment purposes. They have not been peer-reviewed or been subject to the review by the NBER Board of Directors that accompanies official NBER publications.

(C) 2019 by Barry Eichengreen, Asmaa El-Ganainy, Rui Esteves, and Kris James Mitchener. All rights reserved. Short sections of text, not to exceed two paragraphs, may be quoted without explicit permission provided that full credit, including $\odot$ notice, is given to the source. 
Public Debt Through the Ages

Barry Eichengreen, Asmaa El-Ganainy, Rui Esteves, and Kris James Mitchener

NBER Working Paper No. 25494

January 2019

JEL No. F0,H0,N0

ABSTRACT
We consider public debt from a long-term historical perspective, showing how the
which governments borrow have evolved over time. Periods when debt-to-GDP
explosively as a result of wars, depressions and financial crises also have a long his
these episodes resulted in debt-management problems resolved through debase
restructurings. Less widely appreciated are successful debt consolidation episodes,
which governments inheriting heavy debts ran primary surpluses for long periods
reduce those burdens to sustainable levels. We analyze the economic and political
that made these successful debt consolidation episodes possible.
$\begin{array}{ll}\text { Barry Eichengreen } & \text { Rui Esteves } \\ \text { Department of Economics } & \text { Graduate Institute of International } \\ \text { University of California, Berkeley } & \text { and Development Studies } \\ \text { 549 Evans Hall 3880 } & \text { Chemin Eugène-Rigot } 2 \\ \text { Berkeley, CA 94720-3880 } & 1211 \text { Geneva } \\ \text { and NBER } & \text { Switzerland } \\ \text { eichengr@econ.Berkeley.edu } & \text { rui.esteves@ graduateinstitute.ch } \\ \text { Asmaa El-Ganainy } & \text { Kris James Mitchener } \\ \text { International Monetary Fund } & \text { Department of Economics } \\ 70019 \text { th Street, NW } & \text { Leavey School of Business } \\ \text { Washington, DC 20431 } & \text { Santa Clara University } \\ \text { AELGanainy @imf.org } & \text { Santa Clara, CA 95053 } \\ \text { and NBER } & \text { kmitchener@ scu.edu }\end{array}$




\section{Public Debt Through the Ages ${ }^{1}$}

\section{INTRODUCTION}

Sovereign debt is a Janus-faced asset class. ${ }^{2}$ In the best of times it relaxes the domestic constraint on savings, smooths consumption, and finances investment. Investors see it as a safe haven, as delivering "alpha," and as a means of portfolio diversification. In the worst of times it is associated with debt overhangs, banking collapses, exchange-rate crises and inflationary explosions. Investors see it unenforceable, illiquid and prone to messy debt workouts.

In this paper, we use history to analyze both aspects. Historical evidence provides insight into the seasons of darkness by increasing sample size. This helps because defaults on sovereign debt are not as frequent as on, say, corporate bonds. History also can enrich our understanding of those features of sovereign debt that are associated with crisis resolution, since there are variations over time in the structure of debt contracts, their enforceability and the costs of default.

But a long-run perspective is equally useful for understanding the seasons of light. History illustrates how governments have used sovereign debt to shape economic and political development. It shows how they have used it to help build lasting states, provide public goods and complete infrastructure projects. Historical experience sheds light on how sovereign debt evolved into a safe asset, as governments have sought to render it more attractive to investors and, in the course of so doing, underpin the financial system.

History doesn't always unfold at the same pace, and the same is true of this paper. In its first half (Sections 2-4) we review two millennia of debt history in an effort to recover the origins

\footnotetext{
${ }^{1}$ We thank Chengyu Huang for excellent research assistance and Michael Bordo, Mark De Broeck, Marc Flandreau and Kenneth Rogoff for helpful comments. We also thank Ali Abbas, Alex Pienkowski and participants at the IMF conference on Sovereign Debt (September 13-14, 2018) for useful suggestions. A revised version of this paper will appear in "Sovereign Debt: A Guide for Economist and Practitioners, edited by S.M. Ali Abbas, Alex Pienkowski, and Kenneth Rogoff (forthcoming, Oxford University Press and the IMF). This paper was originally published as IMF Working Paper 19/6. The views expressed in this paper are those of the authors and do not necessarily represent the views of the IMF, its Executive Board, or IMF management. (C) International Monetary Fund.

${ }^{2}$ In what follows, we focus on the debt of national (central, federal) governments and not those of state governments, local governments and parastatals except where the latter have been explicitly assumed by the national government, although this distinction is subject to both data and definitional problems, some of which are described below.
} 
of sovereign borrowing. In the second half (Sections 5-7), we then focus on the most recent century of sovereign debt history, with its more direct implications for contemporary policy makers.

\section{Public Debt as State Building}

Though it is challenging to pinpoint precisely when sovereign borrowing began, two criteria can help us identify when political entities first began making concerted use of marketable debt instruments. The first is the existence of the institutions necessary to issue public debt: durable towns, cities, states and nations with well-defined borders; contract laws recognizing polities as entities capable of borrowing; and ledgers for payment and repayment (i.e., accounting systems). ${ }^{3}$ A second criterion is market constraints: the immediate demand for credit by the polity must exceed tax revenues; and a sufficiently large number of individuals other than the sovereign must have wealth sufficient to lend substantial sums.

Although the written record points to instances of public borrowing as long as two thousand years ago, recent scholarship points to 1000-1400 A.D. as when borrowing agreements with states were concluded with regularity and debt contracts entered into by sovereigns were standardized. ${ }^{4}$ Loans to territorial monarchs in Late Medieval Europe, such as those provided by Italian bankers to Edward III during the Hundred Years’ War (1337-1443), were short term and bore high interest rates. $^{5}$ Only after 1500 were territorial states able to borrow long term. Small city-states, in contrast, appear to have been able to borrow at longer maturities already the in $13^{\text {th }}$ and $14^{\text {th }}$ centuries. Epstein (2000) and Stasavage (2011) argue that city-states were able to borrow long

\footnotetext{
${ }^{3}$ Removing the polity from the borrowing equation and replacing it with a single sovereign ruler (as was the case for many historical instances) simplifies the institutional requirements, since the contract can be written between an individual and the sovereign's creditors.

${ }^{4}$ One of the earliest recorded defaults concerns the public borrowing of the Greek city-states that formed the Attic Maritime Association, which had contracted loans from the Temple of Delos during the period 377-373 B.C. The Temple, which acted as a quasi-central bank to Greek city-states, lost roughly 80 percent of its principal when two of 13 city-states completely defaulted, and eight others did so partially. However, such instances appear exceptional until the second millennia A.D. A small treatise attributed to Aristotle collects a series of these anecdotes for the period up to the $4^{\text {th }}$ century B.C. (Aristotle 1920). Roman politicians frequently found themselves in debt, but the Roman treasury sold no bonds or bills (Frederiksen 1966), and neither Ottoman nor Chinese rulers made significant and sustained use of public borrowing (Drelichman and Voth, 2014).

${ }^{5}$ This means high interest rates relative to the risk-free rate. Stasavage (2011) compares interest rates on these loans with the rate of return implied by land rents (his measure of the risk-free rate).
} 
term because they were compact, merchant-dominated polities with representative institutions capable of monitoring the sovereign.

An initial spurt of lending came from the papal finances in the 1260s. Although nominally rich, the Roman Church was hampered by the geographic dispersion of its property and other income sources, such as Peter's pence ${ }^{6}$ Engaged in a long conflict with the Holy Roman emperor, the Church needed a way of paying the troops of its Italian allies. The solution of its Tuscan bankers was to anticipate income from Church property and religious dues. The Church encouraged banking firms to incorporate as joint stock companies as a way of stabilizing this early form of financial intermediation. These new banking firms had legal personalities independent of their investors. They had transferable shares. This new corporate form enabled them to increase their capital base and expand their lending capacity by selling shares and attracting deposits from wealthy individuals (Padgett 2012). They used the resulting income to grant advances to the Church.

This papal model was then emulated by the city-states of the Italian Peninsula. ${ }^{7}$ Debt contracts took the form of annuities called "rentes" and "renten." These specified that lenders would receive a stream of interest payments over their lifetimes or in perpetuity, with the principal never repaid. Perpetuities were liquid because the stream of payments was not tied to the original lender. ${ }^{8}$ They formed the embryo of a permanent stock of public debt, since perpetual annuities could only be redeemed if the city raised sufficient revenue to repay the principal, which was the exception to the rule. ${ }^{9}$ (Life annuities, as noted, expired instead with the death of the original purchaser.) A further advantage of perpetual annuities was that they allowed lenders to circumvent

\footnotetext{
${ }^{6}$ This was the annual tax of one penny from every English householder having land of a certain value paid to the Papal See, from Anglo-Saxon times until it was discontinued in 1534 following King Henry VIII's break with Rome.

${ }^{7}$ Albeit from the unpromising start of “forced loans" raised to deal with military emergencies. Munro (2013) describes how this innovation spread to other European polities, starting with Catalonian cities in the early $14^{\text {th }}$ century.

${ }^{8}$ Owing to this liquidity, they bore lower yields than lifetime annuities. Munro (2013) mentions that in the 1330s, Barcelona issued perpetual annuities with a yield of 7.2 percent and "two-lives" annuities for 14.3 percent.

${ }^{9}$ Visitors to the Italian city of Perugia can admire a rare example of extinction of the public debt stock. In 1234, the commune paid up all its debt and had a stele erected on the cathedral's façade to commemorate the event (Belforti 1843).
} 
religious doctrine on usury; since perpetuities never had to be repaid, theologians regarded them as legitimate contracts under which one party purchased a stream of future income from the other. ${ }^{10}$

The marketability of perpetual annuities created the conditions for the emergence of secondary markets, first locally, then nationally and finally internationally. ${ }^{11}$ Negotiability transformed these securities into what was in effect a public financial good. Investors regarded these government debt instruments as safe, liquid and therefore eligible as collateral in over-thecounter markets. ${ }^{12}$ Although it is uncertain when sovereign debt was first used as collateral, by the end of the early modern period (the $16^{\text {th }}$ through $18^{\text {th }}$ centuries) it had become the dominant form of collateral for short-term credit in Europe. ${ }^{13}$ By expanding the collateral space, government annuities contributed to the development of financial markets, to the expansion of trade, and to the acceleration of growth.

Most immediately, the acceptability of long-term government debt as collateral reduced required returns. Lenders had reason to believe, were they to have to liquidate such collateral, that they could do so at an attractive price. Politically independent city-states with control of their tax bases were thus able to issue long-term tradable debt at around 5 per cent (Pezzolo 2014), noticeably below prior rates. The liquidity and acceptability of these government bonds in turn put downward pressure on the rates on short-term loans to the private sector secured by that collateral. ${ }^{14}$

The supply of loans from city-states and territorial monarchies was driven by the need to finance military campaigns and secure borders. While direct and indirect taxes on trade and consumption might suffice for maintaining borders in peacetime, foreign military campaigns or

\footnotetext{
10 The final theological settlement of the issue was arrived at in the $15^{\text {th }}$ century. It added additional conditions for the legitimacy of perpetual annuities; however, it turned out these were easier to circumvent than then initial prohibition against interest from mutuum (Munro 2013).

${ }^{11}$ Sovereign debt was initially marketed to foreigners by the County of Holland in the $16^{\text {th }}$ century (Neal 2015).

12 As is also often the case today.

${ }^{13}$ For instance, de Luca (2008) documents how city bonds were preferred as pledges in collateralized loans (censi consegnativi) in Milan in the late $16^{\text {th }}$ century.

${ }^{14}$ This virtuous circle or complementarity between public and private credit continues all the way to today's financial architecture, where sovereign bonds provide the long-maturity benchmark asset for asset managers engaged in portfolio diversification and risk management.
} 
the need to repel incursions by foreign troops could overwhelm existing revenue streams. The decline of feudal obligations for military service led sovereigns to create armies for hire, such as the condottieri of Venice, Florence and Genoa. With more than 500 European polities vying for power, war was frequent (Tilly 1992). Sovereign debt thus developed as a vital means of state survival (Stasavage 2011). It enabled the state to finance expenditures of uncertain size and duration. Thus, as states evolved and developed, often in response to war, fiscal capacity did as well (Tilly 1992; Yun-Casalilla and O’Brien 2015).

From the $16^{\text {th }}$ century, Europe's political geography coalesced into the nation states recognized at the Peace of Westphalia in 1648. In parallel, many European states evolved from absolutist regimes to more limited government. Dincecco (2009, 2010, 2011) argues that increased centralization was conducive to the growth of incomes and increased state revenue. ${ }^{15}$ He posits that centralized states, in contrast to absolutist and fragmented regimes, imposed limits on rulers. These states were therefore more responsible fiscally and able to offer lower sovereign yields. This shift in state structure coincided with growing use of sovereign debt to fill fiscal gaps and with the emergence of secondary markets. ${ }^{16}$

From the mid- $17^{\text {th }}$ century, European states accumulated sovereign debts that look positively modern in terms of their shares of GDP, between 20 and 60 percent of national income (Drelichman and Voth, 2014). To be sure, this transition was not uniform. Nor did it obviate the need for costly and sometimes unsuccessful experiments. Absolutist monarchs such as Philip II of Spain still funded their military campaigns by borrowing from international bankers, the most important of whom were based in Genoa. ${ }^{17}$ Drelichman and Voth (2014) show how Genoese bankers were able to align the Spanish king's incentives by forming cartels that prevented competition from interlopers, à la Bulow and Rogoff (1989).

\footnotetext{
${ }^{15}$ This view is consistent with Alesina and Spolaore (2003), who argue that extreme fragmentation and decentralization on the one hand and excessive consolidation and centralization of state power on the other are both likely to be inefficient. Europe in this period can be seen as moving away from extreme fragmentation but not (yet) to excessive centralization (although problems of fractionalization remained, as we recount below when describing the Dutch experience).

${ }^{16}$ These observations are consistent with empirical and theoretical work suggesting the existence of a positive relationship between financial development and a state’s ability to tax (Besley and Persson 2009).

${ }^{17}$ They were a direct outgrowth of that city-states earlier history in dealing with sovereign debt.
} 
The subsequent development of these instruments occurred in states that were sufficiently credible to issue negotiable debt that was traded in impersonal markets, as opposed to among a small number of well-connected bankers. The Dutch provinces, in their long fight for independence from the Habsburg Monarchy, first scaled up this model, and then added an international twist, whereby the securities issued by the central government and cities were marketed beyond the frontiers of the state itself (Tracy 1985).

Notwithstanding its relative success, the Dutch model was hampered by fiscal fractionalization, as individual cities and provinces fought to retain control of their tax bases and minimize their share of central government expenses. This tension arose at a time when the Dutch state was attempting to mobilize against the France of Louis XIV and then England (de Vries and van der Woude 1997). The English mobilized even more extensive financial resources once they overcame the limitations of Dutch finance by developing a broader tax base (the excise tax and a more efficient system of tax collection). Brewer (1989) shows that Britain was able to more than triple its tax take from the late Stuarts to the war of American independence, rendering it a formidable if not always triumphant military power. ${ }^{18}$

Reinforcing these developments was the decision to charter the Bank of England as banker to the government in 1694. Following a series of defeats at the hands of the French, William III's credit was exhausted. In exchange for a $£ 1.2$ million loan, he allowed the subscribers to incorporate as a joint stock company, the Bank of England, that received a banking license and the privilege of issue in London. This was effectively a debt-for-equity swap. ${ }^{19}$ In time, the relation between the Bank and the state moved away from the funding of long-term debt to becoming the government's bank and the public debt office, simultaneously managing the money supply and floating new debt (Roberds and Velde 2014, Neal 2015). Monetary and fiscal policies were comingled in this new

\footnotetext{
18 This stood in contrast to the less elastic land taxes and more costly consumption taxes of Continental Europe. Then, of course, came William Pitt's introduction of the income tax at the end of the $18^{\text {th }}$ century.

19 The British government resorted to similar operations to fund its many wars until the 1740s. In return for forcing more debt onto the Bank's balance sheet, the government granted extensions of the Bank's charter and operations. In 1720, the South Sea Company offered an even more ambitious plan to swap high-yield government bonds with its rising stock. With the burst of the South Sea Bubbly, part of this operation ended up in the Bank's balance sheet. In France, John Law famously scaled up the debt-for-equity model by swapping the whole stock of government debt with stock of the Mississippi Company (Neal 1990).
} 
institution in ways that enabled the English government to fund itself at the lowest rates in Europe, issuing 3 percent annuities, while building up the single largest debt stock (Neal 1990).

\section{From War Finance to Public Goods}

Fiscal states thus evolved in response to the efforts of rulers to secure borders, expand territory and survive. After 1650, larger, more centralized states increasingly possessed the fiscal machinery to raise revenue in uniform ways and had a veto player, such as a parliament, to monitor and discipline public expenditure (Dincecco, 2011, 2015). ${ }^{20}$ Consistent with models in which strong states spend more on public goods (Acemoglu 2005), sovereign borrowing progressively shifted toward the provision of public goods. Domestic public debt took the turn first, with the issuance of bonds to finance education and public works. As incomes rose, manufacturing developed and cities grew, demands arose for clean water, sewers, and still more extensive public education. By the $19^{\text {th }}$ century, sovereign debt was being used to finance everything from water and sewer works to railroads, ports, and canals.

This shift toward public investment acquired additional momentum with the development of global capital markets; foreigners searching for yield beyond their borders found it in debt backed by infrastructure projects, first and foremost railways but other investments as well. Foreign assets rose from 7 percent of world GDP in 1870 to 20 percent in the first decade of the $20^{\text {th }}$ century (Obstfeld and Taylor 2004). Table 1 summarizes investments in sovereign debt and their geographic distribution in the four decades preceding World War I. The first three columns show new issues of external debt by all levels of government in 28 countries since $1880 .{ }^{21}$ The data come from securities listed in the three principal capital markets: London, Paris, and Berlin.

\footnotetext{
${ }^{20}$ The seminal paper on a parliament's ability to monitor the spending of the monarch is North and Weingast (1989) who argue that the English monarch credibly pledged to pursue a sustainable fiscal policy after the Glorious Revolution. This paper spawned a voluminous literature providing further tests of the hypothesis for England (not all of which reach positive conclusions) as well as for other countries. See Dincecco (2015) for a list of references.

21 They therefore provide comprehensive coverage only of the external debt of those nations. The number of countries varies, as we only consider independent nations. In the last period, we include three new sovereignsAustralia, New Zealand and the South African Union.
} 
Table 1. Geographical Distribution of debt flows and stocks, 1880-1914

\begin{tabular}{lcccccc}
\hline \multicolumn{5}{c}{ (Each column made up of percentages that sum to 100) } \\
\hline \multicolumn{5}{c}{ Debt flows } & \multicolumn{3}{c}{ Debt stocks } \\
\hline & Foreign & Foreign & Foreign & Foreign & Foreign & Total \\
& $1880-1889$ & $1890-1899$ & $1900-1913$ & $1913-14$ & $1913-14$ & $1913-14$ \\
\hline \hline Europe & 36.8 & 48.5 & 37.4 & 47.3 & 48.9 & 73 \\
North America & 7.9 & 10.6 & 9.3 & 2.4 & 2.3 & 4.3 \\
Latin America & 47.8 & 12.3 & 21.3 & 9.2 & 9.8 & 5.1 \\
Africa & & & 0.4 & 7.8 & 7.4 & 2.6 \\
Asia & 7.5 & 28.6 & 25.9 & 26.1 & 24.9 & 9.6 \\
Oceania & & & 5.7 & 7.1 & 6.7 & 5.3 \\
\hline Total (USD m) & 957.6 & 1284.5 & 4398.6 & 12729.1 & 13453.1 & 40171.8 \\
\# sovereigns & 26 & 26 & 28 & 28 & 45 & 45 \\
\hline
\end{tabular}

Sources: Bent and Esteves (2016) and United Nations (1946). Values in percentage unless otherwise noted.

Intra-European debt flows accounted for the largest share of new issues, but other regions were prominent in certain periods. Latin America was responsible for almost half of all issues before the 1890 Baring Crisis, for example, after which the share of Asia rose, driven by borrowing by Japan and China.

The last three columns of Table 1 are from a United Nations report tallying sovereign debt stocks on the eve of World War I. This report encompasses both foreign and domestic debt stocks and covers a larger group of economies. The authors estimated the total stock of debt in 1914 to be in excess of $\$ 40$ billion US, $\$ 13.5$ billion of which was foreign debt. The distribution of debt does not change significantly as a result of this broader geographic coverage. But this presentation highlights the importance of domestic debt and the fact that Europe was the most heavily indebted continent. ${ }^{22}$

Not all sovereign borrowing funded productive investment. A considerable fraction financed consumption, including government consumption (Feis 1930; Fishlow 1985; Mitchener and Weidenmier 2010), while other borrowing was for the traditional purpose of war finance. For example, Japan floated its first government bonds in London, at 9 percent in 1870 and 7 percent

\footnotetext{
${ }^{22}$ This last observation is not surprising. European countries had greater fiscal capacity, while emerging nations depended more on foreign finance and were less able to borrow in local currencies at home.
} 
in 1870 and 1873, to support the new Meiji regime’s modernization agenda. ${ }^{23}$ In 1899, Japan then issued bonds in London, New York, and Hamburg in preparation for the impending RussoJapanese war. ${ }^{24}$ Qing China, battling Russia on its Northern border and hostile U.S. and European powers along its coastline, borrowed for defense and to pay reparations. It floated an 8 percent sterling-denominated bond in 1875, a 6 percent issue in 1885, and a 4.5 percent issue in 1898 (this last at an issue price of only 90 percent of face value and secured by customs receipts). It issued domestic bonds in 1894 to finance the First Sino-Japanese War and in 1898 to help pay for the indemnity of the Treaty of Shimonoseki. Both issues predictably lapsed into default when the Qing stepped down in 1912 (Ho and Li 2010).

Even when notionally raising debt to fund public goods, not all emerging economies governments were able to manage their growing debt stocks to avoid insolvency. Box 1 describes the experience of Egypt, where fiscal expansion led first to the loss of financial autonomy and ultimately even political sovereignty.

\footnotetext{
${ }^{23}$ Whereas the first issue financed railway construction, the second was used to pay off the accumulated debts of the earlier feudal regime. The interest rates it was charged were even higher than those paid on marginal credits such as those of Egypt and Romania, reflecting ongoing civil conflict prior to the Meiji's final consolidation of power and the difficulties of building a functioning tax system.

24 These bonds bore an interest rate of 4 percent and ran an impressive 55 years to maturity, arguably reflecting the fact that Japan had gone onto the gold standard in the 1890s (Tomita 2005).
} 


\section{Box 1. Egypt's Debt History in the $19^{\text {th }}$ Century}

The history of public debt in Egypt highlights several 19th century themes: excessive borrowing by local administrations, great power rivalry, loss of financial sovereignty and, ultimately, loss of political independence. Although formally a province of the Ottoman Empire, Egypt acquired substantial autonomy thanks to the efforts of Muhammed Ali, who ruled from 1805. In 1841 a settlement was reached whereby the Porte granted Ali and his successors the title of governor of Egypt (known as Khedive) in exchange for an annual tribute. While this settlement did not grant the privilege of issuing state loans, neither did it exclude it. ${ }^{1}$ Taking advantage of the ambiguity, the Khedive Said (1854-63) issued short-term loans and obtained a personal loan from the Comptoir d'Escompte in Paris to fund the construction of the Suez Canal.

The era of modern state finance started in 1862 with the flotation of a $£ 2.2$ million external loan in London, helped along by the temporarily strong cotton prices produced by the American Civil War. When Khedive Ismail assumed power in 1863, he thus inherited a sizable debt. But rather than consolidating, he borrowed to finance everything from a national road system to an opera house (Landes 1958). By 1876 the funded debt had risen to $£ 69$ million, the floating debt to $£ 26$ million. Since the tax base did not rise commensurately, new loans had to be raised just to fund interest and amortization payments. $^{2}$

Declining cotton prices, the 1873 financial crisis, and the 1875 Ottoman default then closed the markets to Egyptian loans. In an effort to normalize relations, Ismail turned over customs duties, tobacco-monopoly revenues and provincial taxes to representatives of its foreign creditors, organized as the Caisse de la Dette Publique. This was the first application of foreign financial control of the finances of impecunious debtors, a model copied for the Ottoman Empire in 1882, Serbia in 1895 and Greece in 1898 (Mitchener and Weidenmier 2010). The Caisse received the assigned revenues directly from the source and possessed veto power over new borrowing or changes to taxation. ${ }^{3}$ In exchange, it consolidated most of the external debt into a new 7 percent loan. ${ }^{4}$

After uprisings against foreign control and murders of Europeans, Britain bombarded Alexandria and occupied Egypt in 1882, taking charge of government finances (Feis 1930). ${ }^{5}$ The stated policy of the British government had been never to intervene in foreign countries on behalf of the commercial interests of its subjects. But as Platt (1968) and Lipson (1985) observe, exceptions were made for strategic reasons. ${ }^{6}$ In the case of Egypt, commercial, political and financial interests came together.

Among the priorities of the British administration was restoring the solvency of the Egyptian state, which was achieved with the issue of a new loan in 1885 under the guarantee of Britain and five other European governments (Esteves and Tunçer 2016). Under British rule, public revenues increased by 50 percent between 1882 and 1904. Because the Caisse had accumulated large reserves, the French creditors agreed to reduce their control over public revenues. The government used the resulting flexibility to return to the market and convert old debt into new loans paying half the previous rate. 
Between 1882 and 1913, outstanding foreign debt fell from ten times government revenues to half that value. Roads, railroads, and canals, including the Aswan Dam, were constructed using funds from tax revenues, and new loans were placed on international capital markets. Yet, despite this progress, public revenues in Egypt grew the least among its peers under international financial control (Turkey, Serbia, Greece). This was partly because the Caisse, earning ample revenues under the status quo, did little to encourage fiscal reforms, such as re-directing revenues from land tax to indirect taxation and customs revenues, which were cheaper to administer and easier to increase (Tuncer 2015). On the eve of World War I, Egypt thus had one of the weakest fiscal capacities among its peers.

Foreign borrowing by Egypt before and after financial control

\begin{tabular}{cccc}
\hline Period & $\begin{array}{c}\text { Foreign loans } \\
\text { (nominal value in } \mathbf{E m} \text { ) }\end{array}$ & $\begin{array}{c}\text { Effective } \\
\text { interest rate }\end{array}$ & $\begin{array}{c}\text { Debt per capita } \\
\text { (in } \boldsymbol{E} \text { ) }\end{array}$ \\
\hline \hline $1862-1876$ & 69 & 8.5 & 7.2 \\
$1876-1913$ & 55 & 4.5 & 7.5 \\
\hline
\end{tabular}

Source: Tunçer (2015).

${ }^{1}$ The Ottomans themselves only issued their first foreign loan in 1854. However, since all Egyptian taxes were levied under the Ottoman Sultan's authority, the future Egyptian loans would be issued with the Sultan's permission.

${ }^{2}$ The Khedive resorted to increasingly desperate measures, pledging the revenues of his extensive personal estates (Dairas), pre-collection of taxes (in exchange for a 50 percent discount) and selling 45 percent of Suez Canal shares to the British government.

${ }^{3}$ The British and French governments forced dual control over the remaining Egyptian finances by securing the right to appoint two controllers-general (one for revenues and the other for audit and debt) with powers to collect and administer the revenues and expenditures of the Egyptian state.

${ }^{4}$ The new debt service remained unsustainable, however, until a reduction, three years later, of the coupon to 4 percent.

${ }^{5}$ This despite the fact that the French in fact held two-thirds of the debt.

${ }^{6}$ This position is often referred to as the 'Palmerston doctrine' after the erstwhile British foreign secretary, who made it clear in 1848 that "it was entirely a matter of discretion, and by no means a question of international right” whether the British government would support the interests of British bondholders abroad (cit. in Tunçer 2015: 17).

Between a third and half of all domestic investment in Australia, Canada, Argentina, and Brazil in the second half of the $19^{\text {th }}$ century was financed by capital imports (Fishlow 1985). ${ }^{25}$ Edelstein (1982) estimates that, in 1913, Great Britain kept 32 percent of its net national wealth overseas and had allocated 4 percent of its GDP to capital formation abroad

\footnotetext{
${ }^{25}$ A peculiarity of the pre-1914 international debt market was the importance of sub-sovereign borrowers, especially colonies. There was, however, a pecking order of colonial borrowers. Colonies with European settlers issued substantially more debt as share of their economy's output compared to territories whose populations had indigenous majorities (Accominotti et al. 2010; Davis and Huttenback 1986).
} 
every year on average for more than 40 years. Other international financial centers included Paris, Hamburg, Berlin, Brussels, Amsterdam and Zurich. Together with England, France, Germany, Belgium, the Netherlands, and Switzerland accounted for 87 percent of overseas lending in the 1870-1913 period (Maddison 1995).

At the beginning of the $19^{\text {th }}$ century, wealthy households held the majority of sovereign bonds. But with the progress of financial development, banks substantially increased their share (Ferguson 2006). This provided diversification for individual investors, who as small depositors invested indirectly in the market through financial intermediaries, as well as for the banks themselves, while enhancing the safe-asset function of sovereign debt. ${ }^{26}$ By 1883 , foreign government bonds accounted for 23 percent of all securities quoted on the London Stock Exchange (Michie 1999). They still accounted for 21 percent in 1913, far outstripping the share of domestic public debt (Tomz and Wright 2013). ${ }^{27}$

Starting with Amsterdam, but followed by London, Paris and Berlin, the microstructure of the securities market adapted to accommodate foreign bonds (Michie 2006). Large investment houses dominated underwriting and issuance, while specialized market makers provided secondary market liquidity (Michie 1999). Flandreau et al. (2010) suggest that underwriters played a role in regulating sovereign debt issuance by signaling to markets which countries had lower ex-ante default risk. Sovereign spreads were ex-post negatively correlated with underwriter reputation through the end of the $19^{\text {th }}$ century, as more reputable underwriters issued new debt placements of high-quality sovereigns. This signaling function had become less relevant by the end of the $19^{\text {th }}$ century, as the access of investors to information on sovereigns improved. Specialists started issuing financial handbooks with information on foreign governments while the financial press provided coverage of the market. ${ }^{28}$ Bondholder

\footnotetext{
${ }^{26}$ The managed investment fund industry also emerged in this period, first in the U.K. in the late 1860s, and later in the U.S., offering the advantages of liquidity and diversification to the medium-sized retail investor (Chabot and Kurz 2012; Chambers and Esteves 2014).

${ }^{27}$ Domestic debt constituted 14 percent of all securities issued in London in 1913.

${ }^{28}$ Improvements in the circulation of information would not have been possible without breakthroughs in technology, in particular the telegraph and telephone (Michie 1987). On the role of the press, see Scheffers and Roberts (2014).
} 
organizations also acquired the double function of monitoring borrowers and coordinating restructuring negotiations. ${ }^{29}$

Financial integration was reinforced by monetary convergence, as countries and colonies abandoned paper and bimetallic systems for the gold standard. Early empirical work suggested that gold-standard adoption, by eliminating monetary discretion, lowered borrowing costs (Bordo and Rockoff 1996). Subsequent recent research has shown that membership in the gold club did not eliminate currency risk (Mitchener and Weidenmier 2015), although it helped governments to relieve the "original sin" of only being able to sell their debt abroad when denominated in gold (Flandreau and Sussman 2005). A consequence of this growing tendency of states in other regions to tap European capital markets was an increasing comovement of business and financial cycles (Bordo and Haubrich 2010). This manifested itself in the high correlation of sovereign spreads across countries, although that correlation was still lower than today (Mauro, Sussman and Yafeh 2002). It is uncertain whether this correlation heightened the risk of contagious crises (Neal and Weidenmier 2003; Mitchener and Weidenmier 2008). But that debt crises occurred in waves (Reinhart and Rogoff 2009; Reinhart et al. 2016) is at least suggestive of the existence of contagion. ${ }^{30}$

In the $19^{\text {th }}$ century, defaults on external debts were common. Figure 1 plots the incidence of new defaults and the percentage of independent nations under default by decade. ${ }^{31}$ The peaks of the two series are associated with some of the largest international financial crises of the period. The first Latin American debt crisis, starting in 1826, touched almost all the continent and came on the heels of large capital inflows from Europe. The unconditional

\footnotetext{
29 The prototype of such organizations was the British Corporation of Foreign Bondholders, created in 1868 (Esteves 2013; Flandreau 2013).

30 See Bordo and Murshid (2001) and Ba (2017) for further hints in this direction.

31 The number of sovereign nations increased over the century until a maximum of 47 on the eve of the World War. As a consequence, we adapt our calculations to the number of countries effectively independent in each year.
} 
probability of default rose above 5 percent per annum, and by the end of the decade close to a third of all independent nations had defaulted on their external debts. Renegotiation was slow, and only in the 1860s did the fraction of countries in default fall below a Figure 1. Sovereign Default Prevalence, 1800-1913 quarter. $^{32}$ Normalization was shortlived, however, as the new capital bonanza collapsed with the 1873 crisis. The likelihood of new defaults rose to 2.5 percent per annum, and emerging economies were affected disproportionately.

The next spike followed the Baring crisis in 1890. Although the default rate rose above 4 percent per annum, its highest level since the 1820s, the number of defaulting nations rose more modestly and then (In percent)

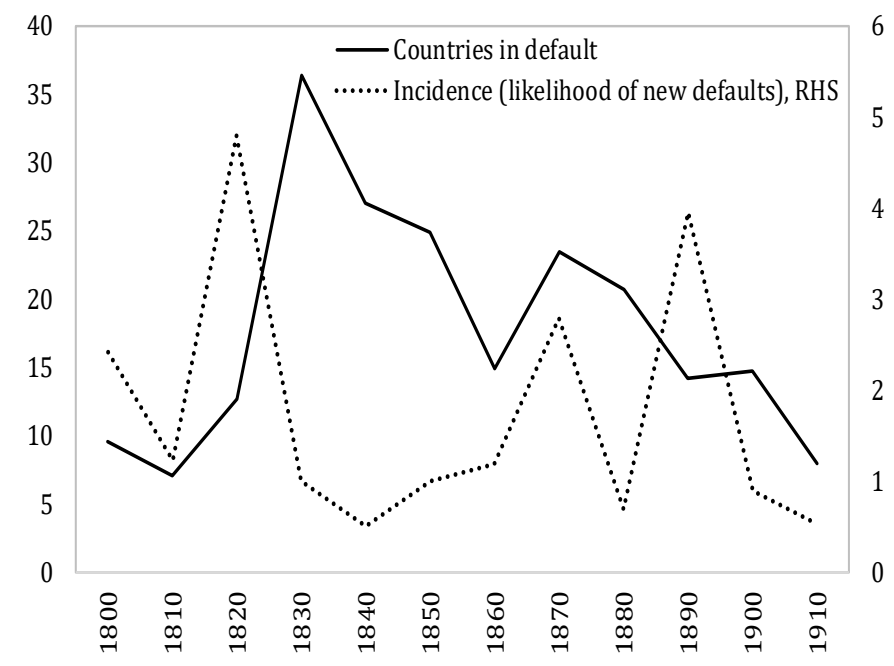

Sources: Reinhart and Rogoff (2009) and authors' calculations.

Notes: Composition of coverage: 47 nations that became independent some time before 1913. The sample includes emerging and advanced economies. See data annex for the list of countries included in the sample. Countries in default refer to the number of independent nations in default in a given year over the total number of independent nations in the same year. Incidence of new defaults refers to the unconditional probability of default per anuum, i.e., the number of defaults per year in a given decade divided by the number of independent nations in the same decade. The data refers to external public debt.

fell continuously until 1913. Defaults were resolved faster than in the early part of the century: according to Suter (1990), the average duration of defaults fell from 14 years prior to 1870, to 8 years in the 1870s and 1880s and 2 years thereafter, with help from bondholders' committees and, in some cases, direct intervention by the governments of creditor countries (Mitchener and Weidenmier 2008). ${ }^{33}$

\footnotetext{
${ }^{32}$ Reinhart and Rogoff (2011) emphasize that sovereigns also frequently defaulted on their domestic debt obligations. These defaults, however, are not very significant in the group of countries represented in Figure 1.

${ }^{33}$ Mitchener and Weidenmier document that creditors, on occasion, imposed "supersanctions" - either placing countries under "fiscal house arrest" by using foreign administrators to collect customs and carry out fiscal administration or by using gunboats to force repayment. Generally, these sanctions were applied against smaller, less-powerful debtors and sometimes reflected the existence of complementary geopolitical motives (proximity to the Suez Canal, the Isthmus of Panama). These mechanisms appear to have been effective: the exante default probability fell by more than 60 percent after a country had been supersanctioned, and risk premiums fell by roughly 200 basis points due to improved fiscal discipline.
} 
The historical literature points to macroeconomic imbalances, political instability and war as among the principal causes of default (Feis 1930; Fishlow 1985; Tomz and Wright 2013; Reinhart and Rogoff 2009). Notwithstanding improvements in the industrial organization of the sovereign debt market, collective-action problems limited the ability of creditors to deter future defaults on sovereign bonds. Reputable underwriters sometimes acted to screen out dubious credits and discourage excessive borrowing, but in an increasingly contestable market they might see their position undermined by new competitors with less reputation at risk (Flores 2011). Strict adherence to the doctrine of sovereign immunity prevented the bondholders from pursuing legal redress. Reputation alone was often insufficient for deterring default when circumstances were unpropitious (Flandreau and Zumer 2004). The conclusion of Lindert and Morton (1989) that "investors seem to pay little attention to the past repayment record of the borrower' may be exaggerated, but it points to the fact that sovereigns were often able to take steps to placate the creditors - negotiating a settlement, undertaking a bond exchange, and going onto the gold standard - and regain market access relatively quickly.

For some countries, default became a recurrent hazard. This is evident if we calculate the probability of default conditional on the number of previous defaults. For the countries covered in Figure 1, the conditional probability of default was relatively low at about 1.5 percent per annum for countries with up to one default prior, but rose to 2.2 percent after two defaults and 4.7 percent after three.

\section{Debt Consolidation Before 1913}

In this section, we describe three notable debt consolidation episodes before World War I: Great Britain after the Napoleonic Wars, the United States in the last third of the $19^{\text {th }}$ century, and France in the decades leading up to 1913. While the colorful debt crises and defaults of the first era of globalization have been much discussed, less attention has been paid to these successful consolidation episodes. We focus on these three cases because they involved three of the largest economies of the period, but also because their debt burdens were among the heaviest. British public debt as a share of GDP was higher in the aftermath of the Napoleonic Wars, for example, than Greek public debt in 2018. But in all three cases, high public debts were successfully reduced relative to GDP. They were reduced in different ways, however, than is typical of $20^{\text {th }}$ and $21^{\text {st }}$ century economies. In particular, there was no restructuring or 
renegotiation of official or privately-held debts in these cases. Nor was there financial repression, i.e., measures artificially depressing interest rates.

Our analysis follows Abbas et al. (2011, 2014a) in decomposing debt changes according to the following debt accumulation equation:

$$
d_{T}-d_{0}=\sum_{t=1}^{T} p_{t}+\sum_{t=1}^{T} \frac{i_{t}-\gamma_{t}}{1+\gamma_{t}} d_{t-1}+\sum_{t=1}^{T} s f a_{t}
$$

Equation (1) states that, the total change in the debt-to-GDP ratio $\left(d_{T}-d_{0}\right)$ over an episode is the sum of three components, each cumulated over the episode years: (i) the primary budget balance $\left(p_{t}\right)$ —-sometimes referred to as the fiscal effort; (ii) the product of the lagged debt ratio and the differential between the effective interest rate on debt $\left(i_{t}\right)$ and the nominal GDP growth rate $\left(\gamma_{t}\right)$ - a term that captures endogenous debt dynamics but can also be thought of as capturing financial repression insofar as the real interest rate is successfully kept below the real rate of economic growth; and (iii) a residual stock-flow adjustment term $\left(s f a_{t}\right) \cdot{ }^{34}$ Box 2 details the nature of the operations captured in this residual term.

\footnotetext{
${ }^{34}$ Note that the decomposition methodology understates the true contribution of economic growth to debt reduction to the extent that high growth eases the political constraints on improving the primary fiscal balance. See Mauro and Zilinsky (2016) for a discussion of an extended decomposition approach that attempts to address this issue. The extended approach is more data-intensive, which is a constraint when analyzing long historical periods as in this paper. It requires strong assumptions about the responses of fiscal variables to growth in order to quantify the additional indirect impact of growth on changes in debt through its impact on fiscal variables.
} 


\section{Box 2. Definition and Interpretation of the Stock-Flow Adjustment}

The SFA captures statistical discrepancies between the actual change in the debt ratio and the sum of the other two components on the right-hand side of equation 1 (the primary budget balance and the growth-interest differential). Such discrepancies can reflect several factors: valuation effects on foreign currency debt, timing effects (deficits are measured in accrual terms while debt is a cash concept), below-the-line operations such as assumption of debts of non-governmental entities, debt restructuring or default, privatization, and bank recapitalization costs. The SFA will also be affected by other forms to support the financial sector that increase the debt but not the deficit, drawdown and buildup of government deposits, transactions in financial assets, and measurement and statistical errors.

According to current conventions, financial sector support measures can affect both deficit and debt. Unless they are financed from cash reserves, they will increase gross debt. Whether they also affect the budget balance depends on whether the operation presents a clear loss for the government. If so, they would be classified as a capital transfer-for example acquisition of financial assets above market price and capital injections to cover bank losses. However, if the government receives shares in a bank or debt securities of equal value to the capital injection it provides, the support measure is classified as a financial operation that only affects the government gross debt. Reclassification of entities from the financial sector to the general government sector (e.g., the nationalization of banks) also increases government debt but not the deficit. (For details, see European Central Bank 2015; Maurer and Grussenmeyer 2015.)

Interpretation of the SFA depends on its sign and on whether the decomposition exercise is undertaken for debt accumulation or debt reduction episodes. In a debt accumulation episode, a positive (negative) SFA increases (reduces) debt. In a debt consolidation episode, a negative SFA means that the debt fell by less (was consolidated by less) than the growth-interest differential and primary surplus would lead one to expect. Put differently, had the SFA been positive in a consolidation episode (implying that it contributed "positively" to the reduction), the decline in debt would have been larger than what was observed, assuming that the contributions of the primary balance and the growthinterest differential are the same. While large SFAs tend to be common during debt surges, they also occur in consolidation episodes (Abbas et al. 2011, Weber 2012). They reflect a host of country-specific factors: domestic institutions (budget transparency), politics (elections), and economic cycles (recessions). The scale of such discrepancies depends on the extent of fiscal transparency in the budget process, among other factors (Alt et al. 2014).

The Napoleonic Wars, Franco-Prussian War and U.S. Civil War were the three most expensive conflicts of the $19^{\text {th }}$ century. Governments and banks were forced to suspend the convertibility of currency into gold (and, in the French case, into silver) while resorting to money creation; but in all three episodes, seigniorage accounted for a relatively small fraction 
of war finance. The majority of war expenditure was financed by taxation and public debt issuance. Consistent with theories of optimal tax smoothing (Barro 1987), debt accounted for the single largest share of wartime financing. Relative to the prewar status quo, taxes were higher during and after the war, but they were raised by just enough to service and pay down the debt.

Britain financed the Napoleonic Wars primarily by borrowing and, in their latter stages, by raising taxes. Once gold convertibility was suspended in 1797, it relied on the Bank of England as a purchaser of government securities. But the increase in the Bank's holdings was limited; these rose from $£ 10$ million in 1797 to $£ 15$ million in 1809 . Debt securities were placed mainly with private investors; the government signaled its commitment to maintaining the real value of its obligations by continuing to amortize debt (maintaining the Sinking Fund established in 1786) and by indicating its intention of restoring gold convertibility at the prewar rate. ${ }^{35}$ In 1799 William Pitt the Younger then introduced the country's first income tax. This contributed fully 20 percent of total tax revenues by 1815. The price level, having risen by 90 percent between 1791 and 1813, was then pushed down to within 10 percent of prewar levels in 1821 , when convertibility was restored. ${ }^{36}$

Union government financing of the American Civil War was not dissimilar. The majority of wartime spending was financed by issuing bonds and raising taxes. Taxes accounted for only a small fraction of resources in 1861-2, but their share rose starting in 1863 with increases in tariffs and excises and the introduction of the first income tax in American history (Pollack 2014). By 1865 a quarter of federal revenues were accounted for by taxes, a slightly higher share than in early $19^{\text {th }}$ century Britain. Bonds held by the banks and lowdenomination notes in the hands of the public rose from $\$ 65$ million to more than $\$ 2$ billion between 1861 and 1865. The most controversial element was the issuance by the Treasury of

\footnotetext{
${ }^{35}$ Bordo and White (1991) cite the government's failure to refute criticism of the Bank of England by the authors of the 1810 Bullion Report as a clear indication of its intention to restore convertibility at the prewar rate. Nonetheless, most of these bonds were sold at a significant discount, reflecting the risk premium understandably demanded by investors in the face of wartime uncertainty. As a result, the resources accruing to the government fell short of the debt obligations with which it was saddled after the wars (MacDonald 2003).

36 "Price level” refers to the Gayer, Rostow and Schwartz index of the prices of domestic and imported commodities.
} 
greenbacks, currency notes not backed by gold, which accounted for 15 percent of wartime government spending. Associated with their emission was a rise in the price level by about 75 percent, slightly less than in Britain during the Napoleonic period. In the U.S., it took until 1878 for prices to be pushed back down to prewar levels and until 1879 for gold convertibility to be restored, a somewhat more extended readjustment than in Britain. ${ }^{37}$

French government expenses in 1870-71 were financed half out of taxes (Hozier 1872). That the war was short limited the need to resort to debt finance. The Bank of France provided direct advances to the government, collateralized by Treasury securities, and in 1871 to the Paris Commune, the Bank's Paris-based directors evidently fearing for their safety. The indemnity transferred to Germany was then financed by two large postwar bond issues, rendering the French government's debt the largest in the world. Still, the yield was just 6 percent, despite the fact that France was defeated and still occupied, testifying to confidence on the part of investors that the authorities would move to stabilize prices, restore convertibility and honor their obligations.

Table 2 illustrates how these high debts were reduced. The starting point in each case is the peak debt-toGDP ratio. The reduction in the British debt-GDP ratio was by far the largest and longest: the debt ratio fell from 194 percent in 1822 to 28 percent nine decades later (see Figure 2). ${ }^{38}$ The French public-debt-

Figure 2. Public Debt and Primary Balance in the United Kingdom (In percent of GDP)

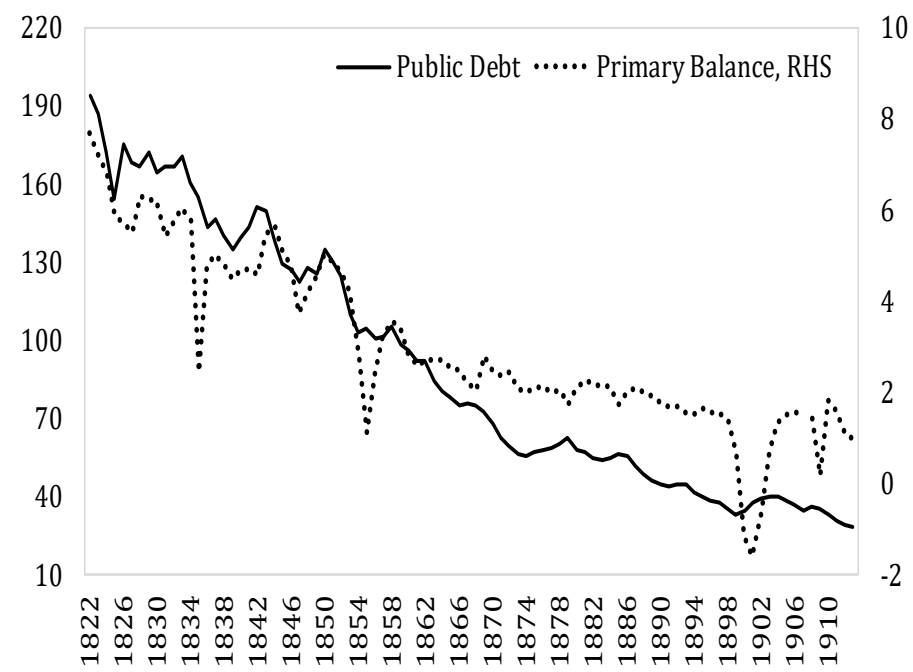

Sources: The Bank of England's database 'A millennium of macroeconomic data: https://www.bankofengland.co.uk/-/media/boe/files/statistics/research-datasets/amillennium-of-macroeconomic-data-for-the-uk.xlsx and authors' calculations.

\footnotetext{
${ }^{37}$ Prices here are the Warren and Pearson index for all commodities.

${ }^{38}$ This is a good place to acknowledge the uncertainty surrounding historical estimates of GDP, which tend to be produced by estimating growth rates in earlier periods and back-casting modern levels of GDP. In the case of the U.K., those early growth rates have been revised downward by recent scholars, resulting in upward revisions of the level of GDP in, say, 1822, when our series for the U.K. begins. We use the most recent estimates of U.K.
} 
GDP ratio fell from 96 percent in 1896 to 51 percent in 1913, after which consolidation was terminated by the outbreak of war. This case ranks second in size but first in pace. ${ }^{39}$ U.S. (federal or union) government debt was not as high at the end of the Civil War, and the subsequent consolidation was more leisurely; however, the process is notable for having reduced the debt-GDP ratio to virtually zero by World War I. ${ }^{40}$

Table 2. Decomposition of Select Large Pre-1914 Debt Reductions

\begin{tabular}{|c|c|c|c|c|c|c|c|c|c|c|c|}
\hline \multirow[b]{2}{*}{ Country } & \multirow[b]{2}{*}{ Period } & \multicolumn{2}{|c|}{ Debt/ GDP ratio } & \multicolumn{5}{|c|}{ Decomposition (in \%) } & \multirow{2}{*}{$\begin{array}{l}\text { Average } \\
\text { real GDP } \\
\text { growth }\end{array}$} & \multirow{2}{*}{$\begin{array}{c}\text { Average } \\
\text { effective real } \\
\text { interest rate }\end{array}$} & \multirow{2}{*}{$\begin{array}{l}\text { Average } \\
\text { inflation } \\
\text { rate }\end{array}$} \\
\hline & & Starting & Ending & $\begin{array}{l}\text { Primary } \\
\text { Balance }\end{array}$ & $\begin{array}{l}\text { Growth-interest } \\
\text { differential (g-i) }\end{array}$ & g & $-i$ & $\begin{array}{l}\text { Stock-flow } \\
\text { adjustment }\end{array}$ & & & \\
\hline UK & $1822-1913$ & 194.1 & 28.3 & 180.5 & -95.6 & 88.4 & -184 & 15.1 & 1.9 & 3.5 & -0.1 \\
\hline USA & $1867-1913$ & 30.1 & 3.2 & 151.1 & -46.3 & 48.2 & -95 & -4.8 & 4.2 & 4.3 & -0.9 \\
\hline France & $1896-1913$ & 95.6 & 51.1 & 100.4 & -1.9 & 96.3 & -98 & 1.6 & 2.6 & 2.9 & 0.5 \\
\hline
\end{tabular}

Sources: authors' calculations; data sources: for the US: Carter (2006); for France: Flandreau and Zumer (2004); for the UK: the Bank of England’s database 'A millennium of macroeconomic data: https://www.bankofengland.co.uk/-/media/boe/files/statistics/research-datasets/a-millennium-of-macroeconomic-data$\underline{\text { for-the-uk.xlsx }}$

In contrast to the post-World War II debt reductions described in Section 7, the growthrate-interest-rate differential did not contribute to the decline of debt burdens in these $19^{\text {th }}$ century episodes. The contribution of this differential was, in fact, negative in all three cases. It was least negative in France after 1896, since it operated over the shortest span and because prices, having trended gently downward for much of the $19^{\text {th }}$ century, turned upward in the mid-1890s, reflecting gold discoveries in the Klondike and Western Australia that reduced real interest rates (Eichengreen 1982).

GDP combining the values for Great Britain from Broadberry et al. (2015) with those of Andersson and Lennard (2018) for Ireland.

${ }^{39}$ Pace is important for these decompositions. For example, while Table 2 shows that the excess of the interest rate over the growth rate was larger for France than the U.S., the contribution of the $g$-i differential to overall debt reduction was smaller, since there were fewer years for that differential to impact. See the discussion below.

${ }^{40}$ In the U.S. case although the difference between the average growth and the average interest rate is small, the $(g-i)$ term still makes a relatively large contribution to debt reduction. The differential was mostly positive in the first 20 consolidation years; the differential was more frequently negative later, when the debt stock was smaller. Thus, the positive differential terms in the early period more than offset the negative terms in the later period, leaving a relatively large contribution of the differential to debt consolidation despite the fact that average $(g-i)$ was small. 
Relatively high coupon rates on debts placed during the wars combined with moderate growth rates and low inflation to produce the negative growth-interest-rate differential. Growth rates were modest during the First Industrial Revolution, since the productivity increase associated with mechanization was limited to a narrow set of sectors (Crafts and Harley 1992). In the French case, economic historians point to a low rate of population increase as a further factor in the slow aggregate rate of growth (Crouzet 2003). Only the United States, a country of immigration and a pioneer in the adoption of modern mass-production methods, displayed what modern observers would characterize as an impressive rate of economic growth. And even in this case, the real GDP growth rate did not exceed the real interest rate.

Governments for their part did little to bottle up savings at home or to otherwise use regulation and legislation to artificially depress yields. The British government did not discourage foreign investment. ${ }^{41}$ French foreign investment was less extensive, but it was actively encouraged by officials as an alliance-building-and-solidifying device (Feis 1930). In the U.S., the National Banking Act of 1863 required federally-chartered banks to hold government bonds as backing for notes, but note issuance was profitable even subject to this proviso.

The negative contribution of the growth-rate-interest-rate differential was compensated for by large and persistent primary surpluses. Britain achieved the impressive feat of maintaining an average primary surplus of 1.6 percent of GDP for nearly a century (the only deficit in Figure 2 is at the time of the Boer War). One of the political legacies of Peel and Gladstone was a fiscal theory or philosophy of "sound finance" emphasizing budget surpluses, low taxes and minimal government expenditure (Campbell 2004). This philosophy was integral to the Victorian economic strategy of free trade, peace and retrenchment, in which trade promoted peace, which in turn permitted military expenditures to be limited. At the same time, faithfully servicing the debt and progressively reducing its burden enhanced the prospects for borrowing in a future conflict and thereby helped to secure the nation. ${ }^{42}$

\footnotetext{
${ }^{41}$ Residents famously allocated as much as 40 percent of their savings to overseas government securities and other foreign instruments, as noted above.

${ }^{42}$ As MacDonald (2003) puts it, the public credit was as vital to the national security as the British navy.
} 
In political terms, this outcome reflected the balance of interests in Parliament, where creditors remained generously represented even after the Reform Acts of 1832 and 1837. As MacDonald (2003) puts it, "The most obvious reason for the firmness of the British commitment to its public debt was the predominance of public creditors within the political system.” It was hard, as he observes, to find a member of Parliament who was not also a bondholder. Successive budgetary reforms starting in the 1820s gave Parliament control over expenditure and allowed it to apply the resulting surpluses to the reduction of the debt stock. A consequence of this political equilibrium was that demands for spending on welfare relief from the disenfranchised masses were kept in check. In exchange, the self-taxing class of income-tax-paying electors relieved the non-electors from the burden of direct taxation (Daunton 2001). Budget surpluses then made feasible further reductions in tariffs and taxes, which reduced the cost of living for the working class (Maloney 1998). ${ }^{43}$

In the U.S., primary surpluses were consistently achieved despite the presence of universal (white male) suffrage (Figure 3). That the economy was expanding strongly, due not just to the growth of per capita GDP but also the number of “capitas” in a country of large-scale immigration made managing the debt burden correspondingly easier (Bayoumi and Bordo 1998). Creditor interests were strongly represented in Congress, especially prior to the

Figure 3. Public Debt and Primary Balance in the United States (In percent of GDP)

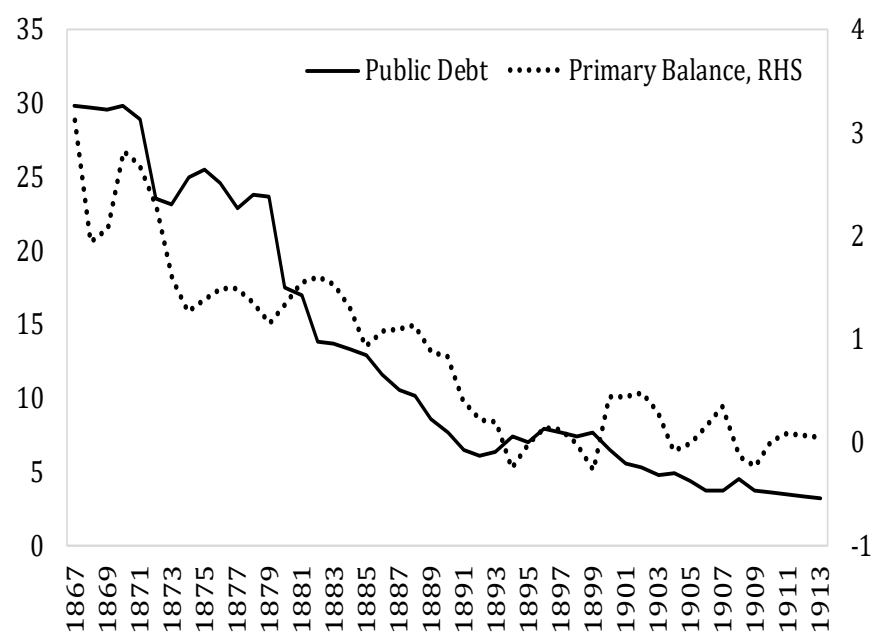

Sources: Carter (2006) and authors’ calculations.

Progressive Era reaction against the "Money Trust." The tariff, defended by the Republican

\footnotetext{
${ }^{43}$ Only with the electoral reforms of the 1880s were the urban and rural poor represented in Parliament. Thus, this political equilibrium reached its limits with these electoral reforms and the increasing organization of unskilled trade unions, whose members could not afford to pay for self-help welfare and the costs of rearmament starting in the 1890s.
} 
Party, provided an elastic supply of government revenues in this period of expanding trade. On the spending side, Southern states opposed an expansive role for the federal government, while entitlements limited to Civil War pensions contained pressure for public spending. ${ }^{44}$

In France, debt reduction was entirely accounted for by primary surpluses. Those surpluses exceeded British levels, reaching 2.5 percent of GDP on average, albeit over a shorter period. ${ }^{45}$ Consolidation was delayed for two decades following the war and payment of the 5 billion franc indemnity to the German Empire (roughly a quarter of one year's French GDP), as French governments first sought to rebuild the economy and then to counter

Figure 4. Public Debt and Primary Balance in France (In percent of GDP)

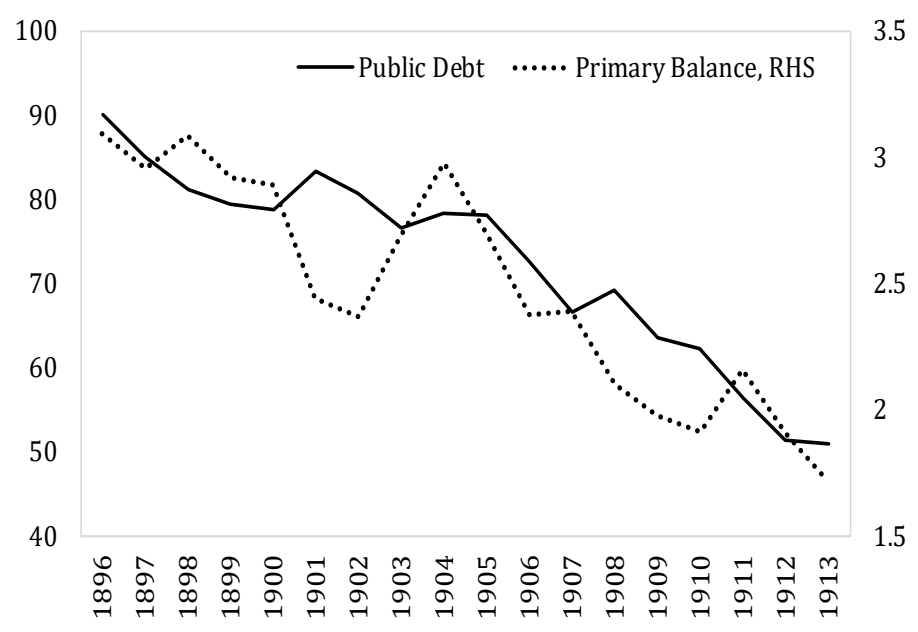

German economic and military

Sources: Flandreau and Zumer (2004) and authors' calculations.

might, investing in roads, railways,

and schools. From the turn of the century, tensions with Germany (and the first Moroccan crisis in 1905) then created pressure for military spending. But even this did not stand in the way of primary surpluses (see Figure 4), governing elites seeing debt reduction as putting the country in a stronger financial position in the event of a full-blown conflict with that country (Dyson 2014). French leaders attributed the country's serial defeats to international conflicts, from the Seven Years' War to the Franco-Prussian War, and to the weakness of French finances, compared to those of Britain and Germany. They now sought to take corrective action.

\footnotetext{
${ }^{44}$ A less unequal income distribution than in the U.K. could also have reduced the pressure for redistribution taxation, as the median voter's income was closer to that of the rich (Lindert 1994).

${ }^{45}$ The primary surplus ratio and annual percentage point reduction in the debt ratio were the same because the initial debt ratio was 100 percent. Analysis of modern data (by e.g., Eichengreen and Panizza 2016) suggests that this is just about the political limit of the primary surpluses that can be sustained over periods of this length. By comparison, the pace of debt reduction was 1.8 percent per annum for Britain and 0.8 percent for the United States.
} 
Another missing element is the SFA. None of these three governments undertook involuntary restructurings despite the inheritance of heavy debt. Only in Britain was the SFA responsible for a nonnegligible share of debt reduction. Its 15 percent share is due to the conversion of the stock of perpetual debt (Consols) from 3 to 2.5 percent bonds undertaken by the Chancellor of the Exchequer George Goschen in 1888. ${ }^{46}$ Interest rates having fallen, these bonds were trading above par. Goschen could threaten to repay the principal at par if they were not converted into new 2.5 percent bonds. The majority was so converted, and the remainder was paid off out of excess Treasury balances. The important point is that the consequent reduction in debt held by the public was voluntary.

Thus, in all three of these large-scale debt consolidations, governments and societies went to great lengths to service and repay heavy debts. This was partly a matter of the enfranchisement and political influence of the creditor class. In part, it reflected prevailing conceptions of the limited functions of government, and limited popular pressure for public programs, entitlements and transfers. In part, it reflected the imperative of maintaining or restoring creditworthiness in order to ensure the capacity to mobilize resources and guarantee state survival. And, in part, it reflected good luck - the absence of major wars and crises during the consolidation period.

\section{Evolution of Public Debt Since 1900}

We turn now to the evolution of public debt since the early $20^{\text {th }}$ century. We consider the G-20 economies together with a set of low-income countries. In classifying countries as advanced, emerging, or low income, we follow the IMF World Economic Outlook categorization. ${ }^{47}$

We distinguish sovereign debt according to its currency composition, maturity and holder profile. Debt structure matters for the level and volatility of debt servicing costs, and for the management of funding (refinancing) and exchange rate risk. Long-term debt generally

\footnotetext{
${ }^{46}$ In addition to Consols, there were relatively small amounts of fixed-term 3 percent debt ("Reduced Threes" and "New Threes").

${ }^{47}$ For advanced and emerging economies, the data start in 1900; for low-income countries they start in 1926 with coverage expanding in the 1950s and again in the 1970s.
} 
commands relatively high interest rates, but rollover risks are lower. Foreign-currency debt can help reduce borrowing costs but exposes the sovereign to exchange rate risks and can increase debt-service costs in the event of currency depreciation. Rising foreign participation can reduce borrowing costs and spread risks more broadly but also raise external funding risks, to the extent that foreign holdings are "less sticky." Finally, higher domestic bank ownership of own sovereign debt can help address funding needs at times of stress, although it can also, under adverse circumstance, create potentially harmful sovereign-bank linkages and threaten domestic financial stability.

Figure 5 is an overview of the evolution of public debt from 1900 to 2015. Prominent there are episodes when wars, recessions and crises produced sharp increases. In the advanced economies, these surges are linked to the two world wars, the Great

Figure 5. Public Debt Ratio

(In Percent of GDP)

Depression, the Great Accumulation

(the mid-1970s through mid-2000s),

and the recession that followed the

Global Financial Crisis. In emerging economies, spikes in the debt ratio occurred in the 1930s and in the 1970s through the 1990s. In the lowincome countries, the major surge was in the 1980s and 1990s. Most of these debt-accumulation episodes were then followed by reversals or consolidations of some magnitude, although the Great Accumulation in the

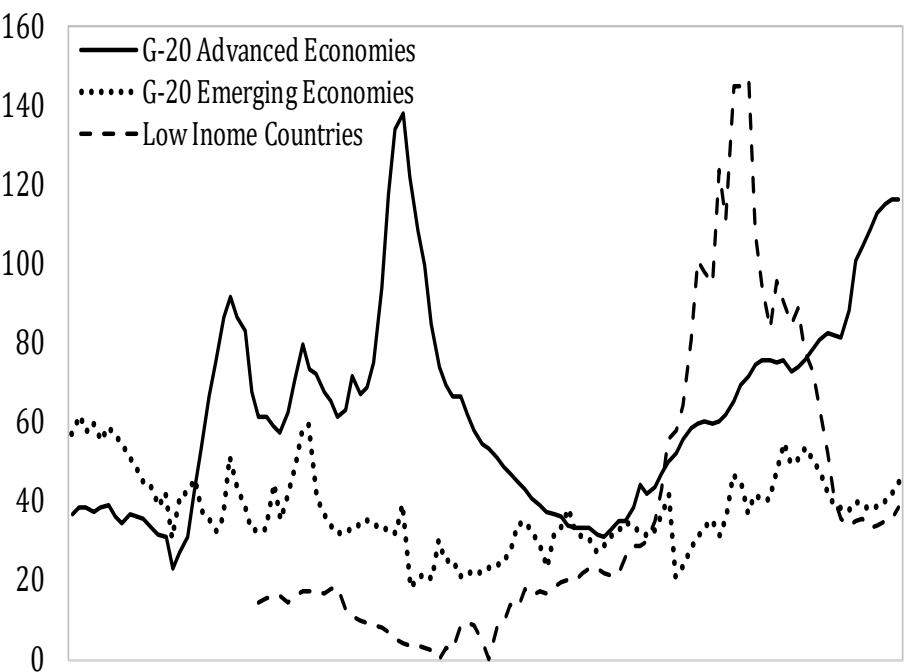

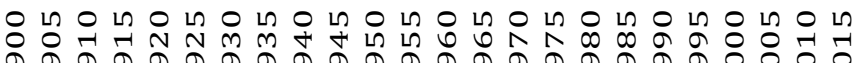

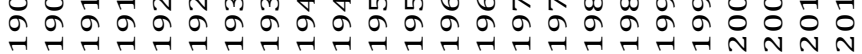

Sources: Abbas et al. (2014a), and latest update of the IMF's Historical Public Debt Database (HPDD). For advanced economies, data up to 2009 are from Abbas et al. 2011, and from 2010 through 2015 are from the latest version of the HPDD. For all other countries data are from the latest version of the HPDD. PPP-GDP weighted averages. up to this point at least. 
Advanced Countries. Debt-to-GDP ratios in the advanced economies averaged 63 percent over the 115-year period. ${ }^{48}$ They declined between 1900 and 1914, reflecting broadly balanced budgets (despite rising military spending) and economic growth (with interruptions, such as at the time of the 1907 financial crisis). ${ }^{49}$ By 1914 advanced-country debt had fallen to 23 percent of GDP, the 115-year low. World War I, the Great Depression and World War II then created new demands for public spending. Together they drove debt up to about 140 percent of GDP in 1946, the highest level in the 11 decades.

A period of consolidation extending into the 1970 s then followed. ${ }^{50}$ Already by 1960 , the halfway point of this interlude, advanced-country debt had fallen to about 50 percent of GDP on the back of strong growth and limited budget deficits, with help from inflation and low interest rates. The Figure 6. Debt Composition in Advanced Economies, Maturity and Currency

(Shares in percent of total public debt, debt ratio in percent) subsequent rise from the mid-1970s through the 1980s coincided with slower productivity growth, expanding welfare states and higher interest rates. ${ }^{51}$ This gradual, sustained rise in debt ratios persisted through the Global Financial Crisis, which gave the trend a further fillip.

Domestic-currency-denominated

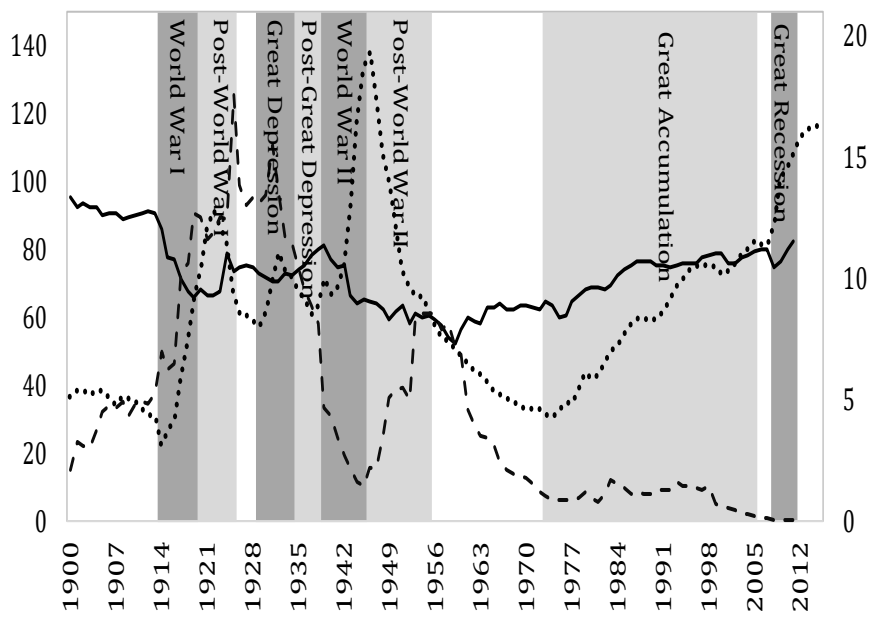
medium-to-long-term (MLT) debt comprised, on average, close to three-

Source: Abbas et al. (2014b).

Notes: G20 advanced economies included are Australia, Canada, France, Germany, quarters of total advanced-country debt

Italy, Japan, the U.K. and the U.S. PPP-GDP weighted averages.

\footnotetext{
${ }^{48}$ Averages are PPP GDP-weighted except where noted otherwise.

${ }^{49}$ Recall the discussion of French fiscal restraint and consolidation in this period in Section 4.

${ }^{50}$ We analyze this episode further in Section 7 below.

${ }^{51}$ Yared (2018) attributes the trend in debt accumulation over the past 40 years in the advanced economies to population aging and the associated rise in popular demands for pensions, health care and other (often unfunded) social services. He argues that political economy theories explain these trends as unintended consequences of mass democracy and its correlates, including rising political polarization and electoral uncertainty across advanced economies.
} 
(Figure 6). Evidently, an inability to issue long-dated debt instruments in local currency was not an issue in advanced economies to the same extent as in emerging economies. ${ }^{52}$

There were exceptions, however. In less favorable times such as wars, crises and recessions, advanced-country governments compensated for the greater perceived riskiness of their debts by shortening maturities. The MLT share fell during World War I, when the authorities sought to meet extraordinary military spending needs using short-term debt. It fell again in the Great Depression and during World War II. The shortening of maturities continued after the war, as inflation eroded investor appetite for long-dated securities. In the United States, for example, this share fell steadily from the 1960s through the late-1970s, coincident with accelerating inflation, although it then recovered sharply starting around the time of the Volcker disinflation. The MLT share then started rising again in the 1980s, in the U.S. and more generally, coincident with inflation stabilization and financial development, and specifically with the growth of investor groups, such as pension funds, mutual funds and insurance companies, with long-term liabilities and hence strong demand for long-term assets. Finally, there were sharp fluctuations around the time of the Great Recession: the MLT share first fell sharply, reflecting heightened uncertainty, but recovered already in 2009-10, as central banks ramped up their purchases of long-term debt.

Although the share of foreign-currency-denominated debt of G-20 advanced economies was low on average (roughly 5 percent of the total), several countries saw it rise sharply at some point in the 11 decades considered here. ${ }^{53}$ In Japan and Italy, shares of foreigncurrency-denominated debt averaged close to 50 percent in 1915-1918 and 1919-1926, respectively. As noted above, Japan borrowed abroad, in sterling, marks and dollars, to finance war with Russia, while Italy tapped foreign markets once the political turbulence of the early 1920s had passed (Meyer 1970). This rise in the foreign-currency share of advanced-economy debt following World War I was general, reflecting the extension of dollar-denominated loans by the United States to its European allies to finance relief and reconstruction. The subsequent

\footnotetext{
52 On the latter, see below.

53 This general trend is consistent with the “original sin” premise that foreign currency indebtedness and the associated risks have not been major issues in advanced economies.
} 
decline in this share during the Great Depression reflected the relief received by the advanced economies on their war-related debts from the U.S. and the U.K. in 1934 (Reinhart and Trebesch 2014). ${ }^{54}$

A final spike in the share of foreign-currency- denominated debt is visible in the immediate post-World War II period. This reflects the rise in the share of foreign-currency debt in Germany in 1953-56, when the Federal Republic negotiated the 1953 London Agreement under which it assumed a share of the predecessor government's debts. ${ }^{55}$ From there, the share of advanced-economy debt denominated in foreign currency declined steadily toward its near negligible levels today. ${ }^{56}$

Figure 7. Debt Composition in Advanced Economies, Holders

The shares of advancedeconomy sovereign debt held by central and commercial banks rose in periods of stress, when individual investors drew back and governments, to take up the slack, leaned on central and commercial banks. This tendency is evident during the two world wars, the Great Depression, and the productivity slowdown of the 1970s (Figure 7).

(Shares in percent of total public debt, debt ratio in percent)

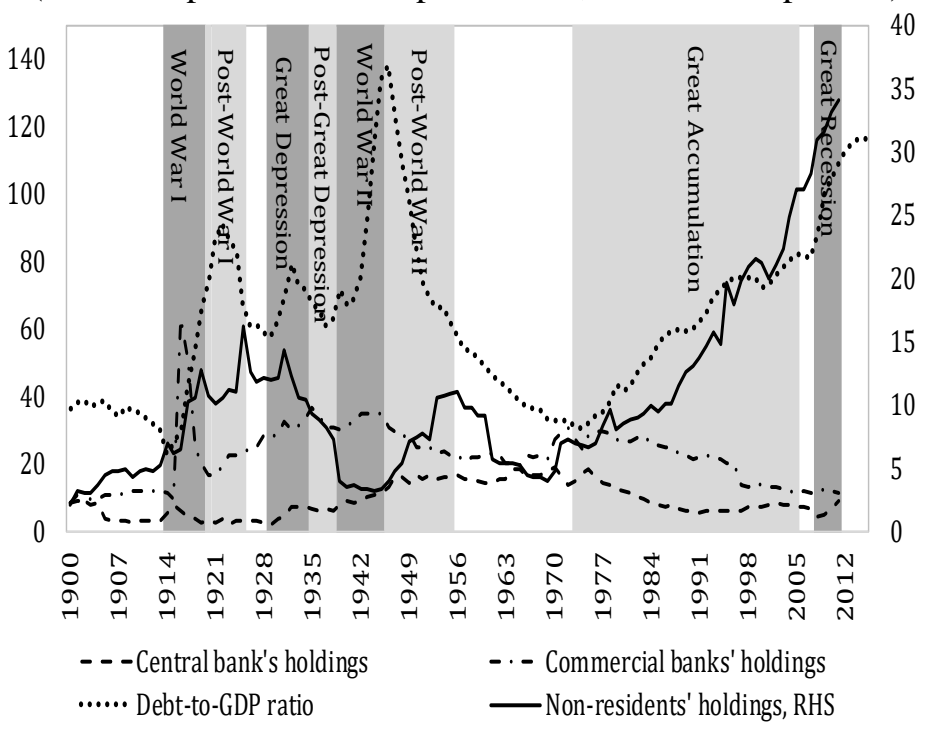

Source: Abbas et al. (2014b).

Notes: G20 advanced economies included are Australia, Canada, France, Germany, Italy, Japan, the U.K. and the U.S. PPP-GDP weighted averages.

\footnotetext{
${ }^{54}$ War debts were the dominant type of indebtedness for many advanced countries in the 1920s. That decade saw some preliminary rescheduling agreements that postponed the repayment of war-related debts but without a reduction in the notional debt burden.

${ }^{55}$ See Guinnane (2004). West Germany assumed some of the debt of the German Reich; there now being two Germanys, the West's lower GDP partly explains the rise in the ratio. During this period, the share of foreign currency debt in Germany rose to more than 40 percent in 1953 and peaked at 45 percent in 1956 (Abbas et al. 2014b).

${ }^{56}$ A few exceptions like the Roosa bonds denominated in Swiss francs that the U.S. government marketed in the 1960s notwithstanding.
} 
The share of advanced-economy own sovereign debt held by national central banks is small on average, at roughly 10 percent. ${ }^{57}$ This share rose in the early 1930s, however, indicative of the stresses of the Great Depression, and then through World War II and in the immediate postwar period, when central bank purchases were part of the inflation-based financial repression through which debt ratios were reduced. The central bank share then trended downward with the development of a broader institutional investor base for government bonds starting in the 1970s, as noted above. The recent uptick in central bank holdings reflects the policy response to the global financial crisis, involving quantitative easing and interventions such as the European Central Bank’s Securities Market Program.

Commercial banks' holdings were more than twice as large as those of central banks over the 115-year period. They were also more volatile, again as evident in the figure. Generally, banks’ holdings increased in periods of stress, such as World Wars I and II. A noticeable decline in this share, however, was observed from mid-1980s, reflecting portfolio diversification facilitated by capital account liberalization and the regulatory changes (the 1988 Basel Accord, which encouraged investment in government securities from other OECD countries by attaching zero risk weights to those bonds). ${ }^{58}$ This decline also coincided with a rise in non-resident holdings during the Great Accumulation period and with the growth of nonbank investment funds.

Emerging Markets. By comparison, public debts have been lower but also more volatile in G-20 emerging economies, averaging 37 as opposed to 63 percent of GDP. Debt accumulation episodes there included the 1920-1930s and 1970s-1980s (both centered in Latin America) and the 1990s (centered in East Asia). U.S. commercial banks first gained a foothold in Latin America when European banks withdrew during World War I and the Federal Reserve Act authorized them to branch abroad. As a result of a strong U.S. current account and of the low interest rates maintained by the Federal Reserve System, U.S. banks were attracted by the

\footnotetext{
${ }^{57}$ This refers to debt held by the domestic central bank, not also by foreign central banks that may hold some foreign treasury securities as international reserves.

${ }^{58}$ This diversification shows up in our data as an increase in foreign holdings and a decline in commercial bank holdings of own-government bonds
} 
high rates on offer in Latin America in the 1920s. ${ }^{59}$ As Latin American governments cashed in on the resulting bonanza, Argentine public debt rose from 56 percent of GDP in 1925 to 118 percent in 1932. Brazilian public debt rose from 21 percent of GDP in 1929 to 52 percent in 1933, Mexican public debt from 18 percent of GDP in 1925 to 38 percent in 1932 for the same reasons. Much of this 1920s-era debt was denominated in sterling or dollars and marketed to foreigners. ${ }^{60}$

Debt ratios then fell from their early-1930s peak, as defaulted debts were restructured, GDP recovered, and budgets were broadly balanced. ${ }^{61}$ Suspension of interest and amortization payments, on external debt in particular, was widespread, reflecting the impact of lower levels of GDP but also weak commodity prices and restrictive trade policies in the advanced economies, which made it harder for debtors to earn foreign exchange. Not just emerging markets in Latin America but also Central European countries unilaterally suspended debtservice payments for significant periods. In some cases, restructuring agreements were negotiated with and received the endorsement of bondholders' committees only after World War II. ${ }^{62}$

The debt-GDP ratio of the emerging market grouping bottomed in 1947, at 18 percent, following the wartime period of inflation. Additional debt was then accumulated via intergovernmental and domestic borrowing, and in the 1970s through foreign-currency borrowing from money-center banks. The process was interrupted in the 1980s by debt crises triggered by sharply higher interest rates and weaker commodity prices (Feldstein 2002; World Bank 2005). Lending resumed once the Brady Plan was launched in 1989, allowing

\footnotetext{
${ }^{59}$ Latin American countries floated bonds on the London market as well in the 1920s, but New York was far and away the larger lender.

${ }^{60}$ Although Reinhart and Rogoff (2011) remind us that this was not the entire story (see below).

${ }^{61}$ Fiscal policy in emerging markets in this period is analyzed by Twomey (1983).

${ }^{62}$ Some authors would include the United States in this category. See footnote 72 below. That the normalization of defaulted debts took so long meant that many emerging markets were unable to borrow externally for extended periods (due to, inter alia, the Johnson Act of 1934, which prohibited foreign nations in default from marketing their bond issues in the United States). Eichengreen and Portes (1986) analyze the determinants of default in a cross-section of countries in the period 1934-38. They find that the share of dollar- and sterlingdenominated debt in default was an increasing function of the debt-GDP ratio and of the deterioration in a country's terms of trade in the preceding period (the so-called "commodity lottery" - see Diaz-Alejandro 1984). They also find that countries that maintained debt-service payments all through the period, including Argentina and the Central American republics, did so in part by running relatively austere fiscal policies.
} 
commercial bank debts to be restructured and securitized and giving the bond market a liquid basis on which to build. Seven-plus years of crisis had to be endured prior to this resolution, during which the high-income countries denied the need for principal reduction, hoping against hope that their banks could rebuild their capital cushions prior to commencing the write-down process.

But with the Brady Plan finally in place, capital flows to emerging economies resumed. A substantial fraction of these new flows financed chronic current-account deficits. Those deficits were associated with the maintenance of pegged exchange rates, which encouraged both lenders and borrowers to discount the risks of foreign-currency-denominated and indexed debt.

Many accounts of public debt in emerging markets emphasize this external aspect, although domestic debt was also important over the first part of the 20th century, as documented by Reinhart

Figure 8. Debt Composition in Emerging Economies

(Shares in percent of total public debt) and Rogoff (2011). The success of emerging economies in placing domestic debt came at some cost, however, in terms of maturity. Figure 8 confirms that in the 19802012 period domestic MLT debt comprised a smaller share of total debt in G-20 emerging economies than G-20 advanced economies (40 percent versus 76 percent). In a number of instances, governments straining to finance current account

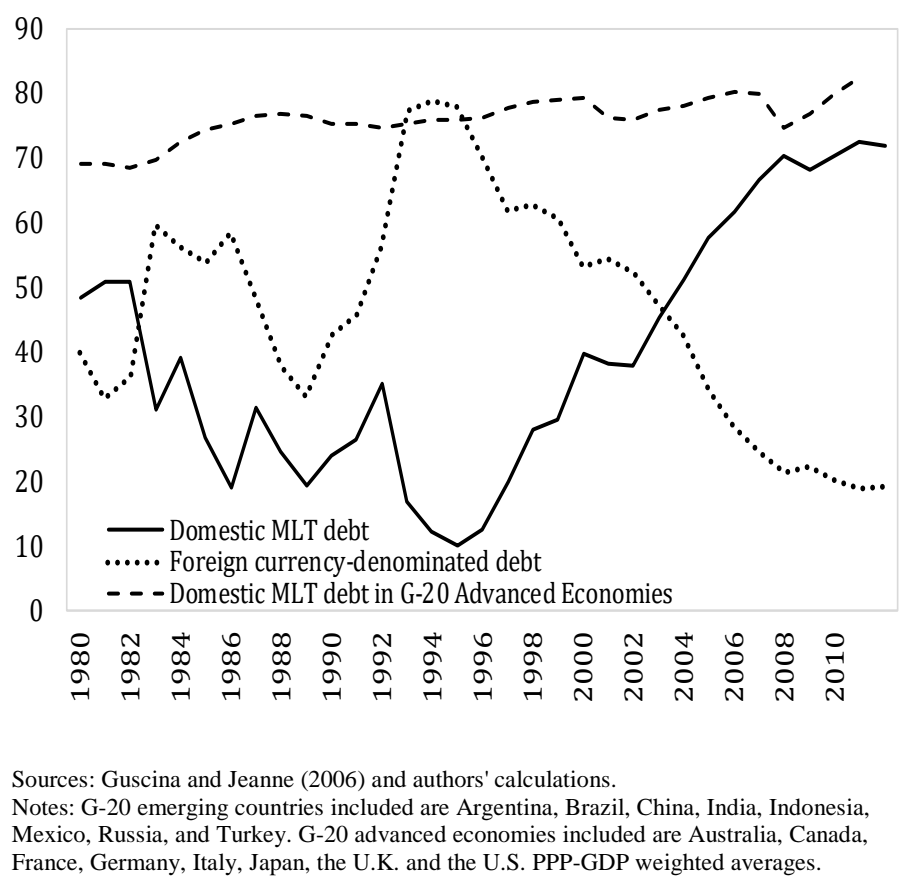
deficits and roll over maturing Mexico, Russia, and Turkey. G-20 advanced economies included are Australia, Canada, France, Germany, Italy, Japan, the U.K. and the U.S. PPP-GDP weighted averages. debts shortened the maturity of new placements. Mexico’s notorious tesobonos were only the most prominent case in point. 
The share of MLT debt rose after the mid-1990s, reaching close to three-quarters of the debt stock in recent years. This has led some to declare the death of "original sin.” Still, the share of debt denominated in foreign currencies remains substantially larger than in the advanced G-20 economies, averaging 46 percent of the total in the 1980-2012 period, compared to close to zero in the advanced economies. That said, after soaring as high as 80 percent in the mid-1990s, the foreign-currency share has been declining since.

Overall, the composition of emerging economies' debt has been riskier, in the sense of a higher combined share of short-term and foreign currency debt. Despite movement in recent years toward a more favorable debt structure, this conclusion still holds.

Low-Income Countries. ${ }^{63}$ Public debt in low-income countries (LICs) averaged 38 percent of GDP between 1926 and 2015 but rose as high as 147 percent in the 1990s. The upturn started the 1970s, as Figure 5 shows. Governments, some newly established, initiated externally-financed public projects with the aim of strengthening their economies and offsetting the 1970s growth slowdown.

Figure 9. Select External Debt Composition Indicators in LICs

The hope, as always, was that (Shares in percent of total external public debt) economies would grow, and favorable export performance would allow debtservice obligations to be met. These optimistic expectations were shaped by prevailing macroeconomic conditions, including the commodity price boom of the early 1970s, and by enhanced access to funding sources. ${ }^{64}$ In the event, much of this external borrowing was used to finance current expenditure rather than developing manufacturing or investing

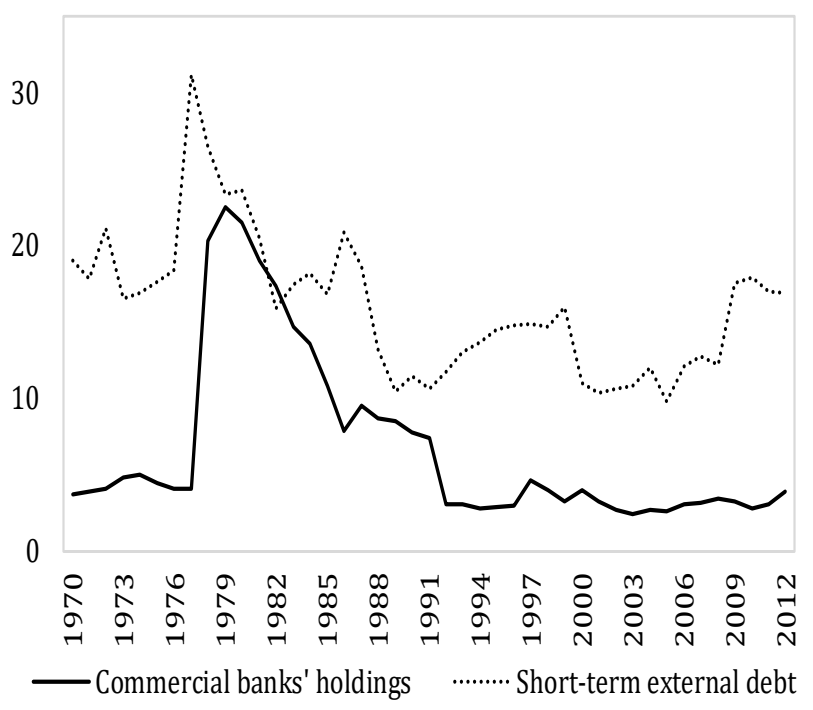

Sources: World Bank International Debt Statistics and authors' calculations. Notes: PPPGDP-weighted averages.

\footnotetext{
${ }^{63}$ See the data appendix for the full list of low-income countries. As noted above, coverage in Figure 5 and elsewhere expands over time, and includes a growing number of countries following their independence.

${ }^{64}$ For example, the Euromarket became a source of finance for LICs that had not borrowed abroad on a significant scale before (Senegal, Togo, Kenya, Zambia, and Liberia, for instance).
} 
in infrastructure (Krumm 1985; Greene 1989), echoing the $19^{\text {th }}$ century experience of serial defaulters. And with the expansion of commercial borrowing, a growing share of the lending was on unfavorable terms, including short durations and variable interest rates (Figure 9).

The developing-economy debt crisis of the 1980s erupted in the wake of the late-1970s oil price shock, unfavorable terms of trade, recession in the advanced economies, and rising global interest rates. Private investors trimmed their exposures and, with export earnings stagnant, countries found it increasingly difficult to service their obligations, resulting in arrears and reschedulings. Many LICs responded not by cutting public spending but instead by borrowing more to fill funding gaps. Civil strife was another factor exacerbating debt burdens, for example in Nicaragua and Uganda and to a lesser extent the Democratic Republic of the Congo and Niger (Brooks et al. 1998). Although multilaterals provided support for adjustment programs, this only left the subject countries more heavily indebted (Easterly 2002; Brooks et al. 1998; Daseking and Powell 1999). ${ }^{65}$ As a result, debt levels rose steadily from the early 1970s, reaching unsustainably high levels by the mid-1990s (Figure 5).

The IMF and World Bank launched the HIPC Initiative in 1996 to provide comprehensive debt relief to the poorest heavily-indebted countries. ${ }^{66}$ The initiative was expanded in 1999 to allow for faster, deeper, and broader relief, and supplemented in 2005 by the Multilateral Debt Relief Initiative (MDRI) ${ }^{67}$ Of the 39 countries potentially eligible for HIPC Initiative assistance, 36 (of which 30 are in Africa) received the full amount of debtrelief for which they were eligible through HIPC and the MDRI. ${ }^{68}$

\footnotetext{
${ }^{65}$ In particular, the IMF's Compensatory Financing Facility came into heavy use during late-1970s and early 1980s.

${ }^{66}$ There had been earlier, more limited initiatives along these lines, as described by Easterly (2002). The limited success of these earlier programs in part reflected the revealed preference of debtors for high debt, which may simply lead to new borrowing to replace old cancelled debts; the granting of progressively more favorable terms for debt relief which may have perverse incentive effects, as countries borrow in anticipation of debt forgiveness and delay policy reforms waiting for the best deal (Easterly 2002).

${ }^{67}$ This was intended to accelerate progress toward the United Nations Millennium Development Goals.

${ }^{68}$ See the data appendix for a list of the countries that have received or potentially eligible to receive debt relief under the HIPC initiative. As of end-August 2016, the total amount of debt relief under the HIPC and MDRI reached \$126.6 billion, with the Democratic Republic of Congo being the largest recipient of debt relief (\$16.3 billion).
} 
According to Easterly (2002) and Gautam (2003), the overall success of the initiative was attributable to two factors. First, relief was conditional on establishing a track record of sound policies, thus avoiding incentives to over-borrow and delay necessary reforms. Second, the initiative was comprehensive: it was a once-and-for-all program in which all creditors, including multilaterals, participated.

\section{Two Debt Accumulation Episodes}

In this section we hone in on the Great Depression and the Great Recession, the two peacetime periods of rapid debt accumulation in the advanced economies. Our discussion follows the debt decomposition approach described earlier. ${ }^{69}$

Though there were parallels between the two episodes, there were also differences. Output and employment losses were much larger during the Depression: real GDP in G-20 advanced economies declined by 4 percent peak-to-trough during the Great Recession but by 19 percent in the Depression. Median unemployment rose to 25 percent at the height of the Depression but remained in the single digits in the Great Recession.

Despite the more severe impact on the real economy, the increase in the debt-to-GDP ratio was less in the Great Depression (24 versus 40 percentage points of GDP). The explanation for the conjuncture of higher output and employment losses with a smaller deterioration in public finances lies in the nature of the policy response and in the initial conditions, i.e., the level of public debt at the onset of the crisis.

Table 3 suggests that about two-thirds of the increase in the advanced-economy debt ratio during the Great Recession was accounted for by the cumulative increase in the primary deficit, reflecting revenue losses on the back of sluggish growth in the aftermath of the financial crisis and, to a lesser extent, expansionary fiscal policies (IMF, 2013).

\footnotetext{
${ }^{69}$ The precise years for which the debt decomposition is conducted for each individual country varies so as to best capture trough-to-peak (peak-to-trough) in its buildup (consolidation) episode. We focus on sustained changes in debt ratios rather than temporary reversals that were small relative to duration and size of the episode identified.
} 
Table 3. Decomposition of Select Large Post-1914 Debt Increases

\begin{tabular}{lccc}
\hline \multicolumn{4}{c}{ (Contribution to debt increase, percent as share of total) } \\
\hline & $\begin{array}{c}\text { Primary } \\
\text { balance }\end{array}$ & $\begin{array}{c}\text { Interest-growth } \\
\text { differential }\end{array}$ & $\begin{array}{c}\text { Stock-flow } \\
\text { adjustment }\end{array}$ \\
\hline Great Depression (1928-33) & -9 & 108 & 1 \\
Great Recession (2007-13) & 67 & 25 & 8 \\
\hline
\end{tabular}

Source: Abbas et al. (2014a) and authors' calculations.

Notes: Countries included are Australia, Canada, France, Germany, Italy, Japan, the U.K., and the U.S. PPPGDP-weighted averages, cumulative over the episode years.

In the U.S., the stimulus package enacted in early 2008 targeted tax cuts at low- and middle-income families. This was followed by tax relief for first-time homebuyers and by the 2009 American Recovery and Reinvestment Act (ARRA), which authorized nearly \$800 billion of stimulus. The largest countercyclical fiscal action in the U.S. history, the ARRA had important implications for the debt ratio. Australia, Canada, Germany, Japan and the U.K. similarly enacted fiscal stimulus packages by late 2008. Early measures generally took the form of tax cuts, while increases in spending, such as extensions and expansions of unemployment benefits, were deployed subsequently. Public investments were undertaken with longer lags, reflecting project evaluation and procurement procedures, although bringing forward pre-planned capital expenditures mitigated this delay in cases such as France and the U.K. (IMF 2013). ${ }^{70}$

By comparison, there was little discretionary countercyclical fiscal action in the 1930s. Where the primary balance accounted for two-thirds of all debt accumulation in 2007-13, its

\footnotetext{
${ }^{70}$ On the monetary policy front, central banks (in the U.S., the U.K. and Japan, followed eventually by the Euro Area) reduced interest rates (for instance, in the U.S., the zero lower bound was reached by end-2008). After cutting rates, they implemented a range of unconventional monetary policies aimed at restoring the functioning of financial markets and intermediation, and providing further monetary stimulus at the zero lower bound. Forward guidance and quantitative easing in the form of government bond purchases were used to lower longterm interest rates. Negative interest rates on bank deposits at central banks have also been deployed in some countries. Through these channels, and by helping to secure recovery, these policies helped to narrow and reverse the interest rate-growth rate differential.
} 
contribution was negative in 1928-33, when primary balances were, on average, in surplus. ${ }^{71}$ In the U.S., however, the Revenue Act of 1932 increased tax rates with the goal of balancing the federal budget. The New Deal, initiated in early 1933, included new programs aimed at generating recovery but represented only a modest and temporary countercyclical fiscal expansion (Brown 1956). ${ }^{72}$

The U.K., like the U.S., did not make much use of fiscal expansion in the early stages of its recovery (Middleton 1984). France raised taxes to defend the gold standard in the first half of the decade but then ran substantial budget deficits only after $1936 .{ }^{73}$ Germany and Japan, however, saw large increase in government spending from the mid-1930s. The German budget deficit as a percent of GDP increased little initially but grew substantially after 1934 as a result of public works and rearmament (Thomas 1934). Japanese government spending, particularly military spending, rose sharply between 1932 and 1934, resulting in substantial budget deficits (Almunia et al. 2010). This fiscal stimulus, combined with monetary expansion and an undervalued yen, returned the Japanese economy to full employment relatively quickly.

Another difference is the role of SFA, which contributed more to the increase in the debt ratio in the Great Recession. This reflected extensive financial sector support in several advanced economies and loans to support the housing sector, which were not recorded as

\footnotetext{
${ }^{71}$ Governments were smaller during the Great Depression - the expenditure-to-GDP ratio averaged 8 (40) percent during the Great Depression (Great Recession). Larger governments during the Great Recession were associated with bigger automatic stabilizers, which contributed more to the deterioration in the fiscal balances compared to the Great Depression.

${ }^{72}$ Starting in 1933, the U.S. took monetary measures to prevent prices (and nominal GDP) from falling further and from increasing the contribution of the growth-interest differential even more. The Roosevelt Administration took the country off the gold standard and devalued the dollar against gold by approximately 50 percent. Romer (1992) points to the associated monetary expansion as the main factor supporting the recovery of real GDP in the subsequent period. In order for the government to abandon the gold standard and depreciate the dollar against gold but not also push up the nominal value of the debt, the U.S. Supreme Court had to uphold the constitutionality of the abrogation of the gold clauses in U.S. government debt securities. Those clauses guaranteed holders payment in dollars of constant gold content, meaning that had they not been abandoned a 50 percent devaluation against gold would have required an increase of 50 percent in current dollar interest and amortization payments. Whether abrogation of the gold clauses should be thought of as a debt default is disputed. For the latest on this, see Edwards (2018).

${ }^{73}$ The expansionary effect of these deficits, however, was counteracted by a legislated reduction in the French workweek — a change that raised costs and depressed production (Cohen-Setton et al. 2017).
} 
spending and therefore show up as contributions of the SFA to debt dynamics. ${ }^{74}$ Governments intervened in distressed financial systems and industry in the 1930s as well, but they relied, on average, more on approaches that did not increase recorded sovereign debt. ${ }^{75}$

But the small average contribution of the SFA to the debt buildup in this period masks cross-country variations. The SFA contributed more, for example, to the rise in debt in a small subset of our countries, most notably Japan, where it reflected the operations of the Industrial Bank of Japan, which engaged in extensive off-balance-sheet transactions. France, where the SFA adjustment made the largest negative contribution to debt accumulation, remained on the gold standard throughout the period analyzed here, when countries such as the U.S. depreciated their currencies. We suspect that the negative SFA for France reflects reductions in the burden of foreign-currency-denominated debt, supported by the maintenance of the gold standard (the opposite of the country's experience in the first half of the 1920s - see below).

Hence, the Great Depression debt surge was fully accounted for by the growth rateinterest rate differential, reflecting the large negative shock to output and employment. Eventually currency devaluations enabled central banks to cut policy rates and then stabilize and raise prices, translating into a reduction in real interest rates. These policies, along with relatively low initial debt levels, contained the impact of the interest-rate component on debt dynamics. They help explain why the increase in debt ratios, in percentage point terms, was smaller than in the Great Recession. ${ }^{76}$

\footnotetext{
${ }^{74}$ Changes in governments' financial assets (which capture, among other items, loans to other sectors) accounted for about 90 percent of the SFA term, on average, over this period.

${ }^{75}$ In many cases, support for the financial sector was provided by the central bank or in the form of government guarantees and not reported as an increase in government spending, government financing or public debt. For example, German banks were kept afloat by central bank liquidity provision and government guarantees, financial injections that never showed up on the government's balance sheet. In the case of the U.S. Reconstruction Finance Corporation (RFC), the majority of public finance for bank recapitalization was provided directly by the Treasury, which gave the RFC $\$ 500$ million of capital and then additional loans, and which sold bonds to the public to fund the RFC. Treasury funding totaled \$50 billion over the RFC's approximately 25-year lifetime (thus averaging $\$ 2$ billion a year); by comparison, U.S. GDP in 1939 was on the order of $\$ 100$ billion. The RFC was also authorized to sell bonds to the public ( $\$ 3$ billion in total), operations unlikely to be captured by the SFA.

${ }^{76}$ Advanced-country debt was much higher in 2007 than at the start of the Great Depression (84 versus 57 percent of GDP). For the same output and unemployment shock, the snowball effects on public debt were therefore larger starting in 2008.
} 
Debt maturities and the composition of debt holders also evolved differently (Table 4). During the Great Depression, the share of domestic short-term debt increased as governments were forced to accept less favorable conditions (shorter maturities) on new issues. ${ }^{77}$ The period also saw a fall in the share of non-resident holdings, consistent with the decline in trade and capital flows, the imposition of capital and exchange controls, and defaults on external obligations. Commercial bank holdings of government securities rose as investors substituted away from other riskier investments. ${ }^{78}$

\section{Table 4. Shifts in Advanced Economies’ Debt Composition, Select Debt Buildup Episodes}

\begin{tabular}{|c|c|c|c|c|}
\hline \multicolumn{5}{|c|}{ (Shares in percent of total debt, PPPGDP-weighted averages) } \\
\hline Great Depression & 1928 & 1933 & Change & $\begin{array}{c}\text { Cumulative annual } \\
\text { change (1931-33) }\end{array}$ \\
\hline Short-term debt & 8 & 15 & 7 & 1 \\
\hline Central bank holdings & 2 & 7 & 5 & 3 \\
\hline Commercial banks' holdings & 28 & 30 & 3 & 2 \\
\hline Non-resident holdings & 12 & 11 & -2 & -2 \\
\hline Great Recession & 2007 & 2011 & Change & $\begin{array}{l}\text { Cumulative annual } \\
\text { change }(2009-11)\end{array}$ \\
\hline Short-term debt & 20 & 17 & -2 & -8 \\
\hline Central bank holdings & 7 & 9 & 2 & 5 \\
\hline Commercial banks' holdings & 11 & 12 & 1 & 0 \\
\hline Non-resident holdings & 28 & 34 & 6 & 3 \\
\hline
\end{tabular}

Sources: Abbas et al. (2014b) and authors' calculations.

Notes: Countries included are Australia, Canada, France, Germany, Italy, Japan, the U.K., and the U.S. Averages in PPP-GDP weighted terms.

The Great Recession, in contrast, saw a shift away from short-duration debt. ${ }^{79}$ Central bank holdings increased in both periods, although Table 4 shows that their holdings rose more rapidly after 2009 than after $1931 .{ }^{80}$ Starting in 2008, demand by commercial banks was

\footnotetext{
77 This shift was especially evident at the onset of the Depression. Compare the last two columns of Table 4. Bordo et al. (2003) also point to the shortening of maturity in several advanced economies during the Great Depression.

${ }^{78}$ On the increase in commercial banks' holdings see League of Nations (1934), Appendix III.

${ }^{79}$ There was however a move towards shorter maturity and foreign currency debt issuance in some more troubled Eurozone countries, Cyprus, Greece, Ireland and Portugal for example (De Broeck and Guscina 2011).

${ }^{80}$ In the case of the Great Depression, the increase in central bank holdings evident in the top panel of Table 4 is driven by the case of Japan (see above).
} 
sustained by continuing to attach zero risk weights and capital charges to sovereign obligations from OECD countries. ${ }^{81}$ Demand by non-residents, for U.S. government debt in particular, picked up despite low yields, reflecting flight to safety and the so-called safe-asset shortage. Non-resident holdings had climbed on the back of financial innovation and globalization, enabling countries to finance their deficits by issuing MLT debt to both domestic and nonresident holders while reducing their reliance on central banks.

\section{Two Debt Consolidation EPISODES}

In section 4 we discussed three cases of countries that successfully reduced their debts in the pre-1914 era. Here, we turn to two prominent consolidation episodes in the advanced economy following the two $20^{\text {th }}$ century world wars. Very different approaches, it turns out, were pursued in the two periods.

Advanced-Economy Debt Consolidation after World War I. In the interwar period, advanced economy debt reductions were achieved partly through economic growth, partly through restructurings of external obligations, and partly through primary surpluses. The growth-interest differential contributed less in the 1920s than after World War II, given that the twenties were a period of deflation, not inflation. ${ }^{82}$ Balanced budgets were the norm; net of interest payments, those budgets delivered primary surpluses that helped to reduce debt ratios (Table 5). However, the SFA worked against consolidation. This term was driven by France, which had significant dollar-denominated debt in the early 1920s. ${ }^{83}$ Depreciation of the franc increased the burden of those debts, which shows up as a negative SFA (and an increase in the debt ratio) in a period of consolidation (when debt is being reduced).

\footnotetext{
${ }^{81}$ Whatever the underlying creditworthiness of the sovereign in question and whatever the other demerits of the policy.

${ }^{82}$ Instances of hyperinflation, which had a powerful impact in eroding the burden of MLT debt, notwithstanding to the contrary.

83 The sizable dollar denominated debt was incurred as a result of the four liberty loans the U.S. extended to France during World War I. In the early 1920s, the share of foreign-denominated debt rose significantly in France (from 24.5 percent in 1921 to about 40 percent in 1925) and stabilized at that level through the early 1940s.
} 
Table 5. Decomposition of Select Large Post-1914 Debt Reductions

(Contribution to reduction, percent as share in total)

\begin{tabular}{lccc}
\hline & $\begin{array}{c}\text { Primary } \\
\text { balance }\end{array}$ & $\begin{array}{c}\text { Growth-interest } \\
\text { differential }\end{array}$ & $\begin{array}{c}\text { Stock-flow } \\
\text { adjustment }\end{array}$ \\
\cline { 2 - 4 } Post-WWI (1921-29) & 64 & 53 & -16 \\
Post-WWII (1945-75) & 46 & 75 & -21 \\
\hline
\end{tabular}

Sources: Abbas et al. (2014a) and authors' calculations.

Notes: For post WWI, the countries (episodes) included are: Canada (1922-28); France (1921-26), the UK (1923-29), the US (1921-29). For post-WWII, countries (episodes) included are: Australia (1946-63), Canada (1945-57), France (1949-69), the U.K. (1946-75), and the U.S. (1946-74). PPPGDP-

weighted averages, cumulative over the episode years.

Rescheduling of bilateral government credits in the early 1920s postponed repayments to the U.S. and the U.K. without reducing the nominal debt burden. ${ }^{84}$ These maturity extensions, evident in Table 6, were facilitated by the fact that a substantial fraction of this debt was held by the foreign official sector, reflecting inter-government obligations incurred during the war. The share of foreign-currency-denominated debt remained relatively high. It increased further in the immediate post-World War I period, as foreign loans from the U.S. to Europe were used to fund relief and reconstruction. That the share of foreign- currency denominated debt was high meant that it was not easily inflated away. ${ }^{85}$

Ultimately, the overhang was removed by large-scale war-debt reduction, which also delivered a fall in the share of foreign-denominated debt (Table 6). The Hoover Moratorium in 1931 allowed 15 European countries to suspend their war-debt payments to the U.S., and at the 1932 Lausanne Conference the U.K.'s wartime allies were permitted to temporarily suspend their payments. These suspensions were recognized as permanent in 1934. War debt relief accounted for 36, 43, and 52 percent of 1934 GDP for France, Greece and Italy respectively (Reinhart and Trebesch 2014). In Germany, external public debt contracted in the second half of the 1920s was written down unilaterally in 1933-34, when the National Socialist

\footnotetext{
${ }^{84}$ Select war debt reprofilings occurred later (e.g., Austrian debt to the U.S. in 1930 and Romanian debt to the U.K. in 1937), but since these are not G-20 countries these reprofilings are not reflected in our calculations.

${ }^{85}$ Note that Table 5 (and Figure 5 above) do not include reparations obligations from Germany as public debt; doing so would greatly alter (and dominate) the analysis.
} 
regime was no longer deterred by ensuing damage to its commercial and diplomatic relations (Ritschl 2013).

Table 6. Shifts in Advanced Economies’ Debt Composition, Select Debt Reduction Episodes

\begin{tabular}{lcccc}
\hline \multicolumn{4}{c}{ (Shares in percent of total, PPPGDP-weighted averages) } \\
\hline Post-WWI & $\mathbf{1 9 2 2}$ & $\mathbf{1 9 2 9}$ & Change & $\begin{array}{c}\text { Cumulative annual } \\
\text { change (1922-25) }\end{array}$ \\
MLT domestic debt & 66 & 73 & 6 & 7 \\
Foreign currency debt & 12 & 13 & 1 & 6 \\
The 1930s & 1932 & $\mathbf{1 9 3 9}$ & Change & $\begin{array}{c}\text { Cumulative annual } \\
\text { change (1932-35) }\end{array}$ \\
Short-term debt & 15 & 14 & -1 & 2 \\
Foreign currency debt & 14 & 5 & -9 & -5 \\
\hline
\end{tabular}

Sources: Abbas et al. (2014b) and authors' calculations.

Notes: Countries included are Australia, Canada, France, Germany, Italy, Japan, the U.K., and the U.S. PPP-GDP weighted averages.

Advanced-Economy Debt Consolidation after World War II. Post-World War II debt consolidation, from the mid-1940s through the mid-1970s, was the most dramatic such episode in the $20^{\text {th }}$ century. G-20 advanced economy debt reached 140 percent of GDP in 1946, as noted, Figure 10. Interest-Growth Differential in Advanced Economies (Difference in percentage points) before falling to 30 percent by 1974 . Three quarters of the reduction was accounted for by the growth-rateinterest-rate differential, with primary surpluses playing a smaller role (Table 5). ${ }^{86}$ The favorable differential reflected reconstruction of the international economy, strong investment, and

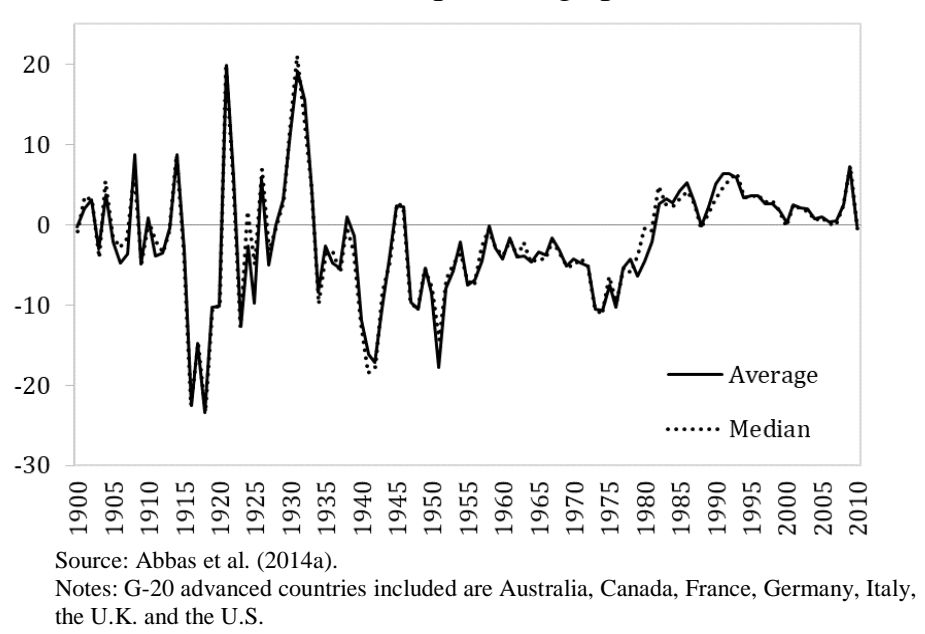

\footnotetext{
${ }^{86}$ The contribution of the primary surplus varied across countries: it contributed half of the reduction in debt in the U.S. during 1946-74, for example, but only a quarter in the U.K. over the same period.
} 
successful catch up (Eichengreen 1996). Also important were negative real interest rates (Figure 10) supported by restrictive domestic financial regulation, widespread capital controls and persistent inflation (Reinhart and Sbrancia 2015). Regulatory restrictions included interest rate ceilings and reserve requirements on banks, prudential floors on pension fund assets to be held as government securities, caps on bank deposit rates, and restrictions on cross-border foreign exchange transactions. ${ }^{87}$ Exchange and capital controls were applied in the 1930s and persisted after World War II. The international bond market, remained Figure 11. Central Bank Holdings of Government Debt in the U.S. quiescent, demoralized by earlier defaults and by the Johnson Act (described above). Governments consequently shifted toward domestic funding. Central bank holdings of government paper were high in this period, and to the extent that their accumulation represented the monetization of fiscal deficits, they facilitated inflation. In the U.S., the central-bank share of government debt (In percent)

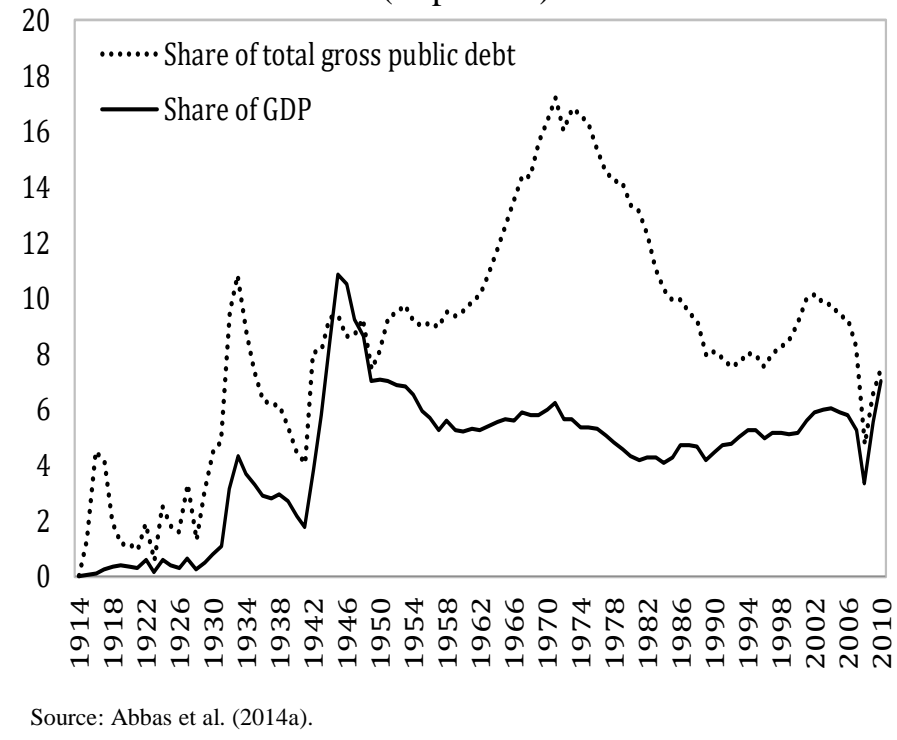
reached a record 17 percent of gross debt in the early 1970s (Figure 11). The accumulation of government debt by the Fed in the pre-1951 Accord period is well-known (see e.g., Eichengreen and Garber 1991): the central bank accumulated public debt as needed to maintain the Treasury-dictated ceiling on interest rates. That the share of gross debt on the central bank's balance sheet again rose strongly in the 1960s is perhaps less widely appreciated.

The roles of inflation and central bank financing in these consolidations differed. Japan experienced high inflation from 1946 through 1949. ${ }^{88}$ (The 12-month change in retail prices in Tokyo peaked at more than 700 percent in late 1946). In the U.K., in contrast, the roles of

\footnotetext{
${ }^{87}$ Before World War II there was a gradual shift towards heavier regulation in response to the financial crises of 1929-32. The legacy of these crises made it easier to package those policies as "prudential."

${ }^{88}$ The Dodge Line Stabilization took place in mid-1949, but even then, it took an additional six months for inflation to come down to single-digit levels.
} 
inflation and central bank financing were less, and the rate of debt reduction was only half as fast. But faster debt reduction in Japan, achieved through inflation, came at the expense of significant maturity shortening, reflecting declining investor appetite for long-dated securities (Table 7).

Table 7. Shifts in Select Advanced Economies’ Debt Composition, Post-WWII

\begin{tabular}{lcccccc}
\hline $\begin{array}{c}\text { Country } \\
\text { (Episode years) }\end{array}$ & $\begin{array}{c}\text { Debt Reduction relative } \\
\text { to intitail debt level }\end{array}$ & No. of years & $\begin{array}{c}\text { Average debt } \\
\text { reduction per year }\end{array}$ & $\begin{array}{c}\text { Average } \\
\text { inflation }\end{array}$ & $\begin{array}{c}\text { MLT domestic } \\
\text { Debt }\end{array}$ & $\begin{array}{c}\text { CB } \\
\text { Holdings }\end{array}$ \\
\hline (percent) & (years) & $\begin{array}{c}\text { (percentage points } \\
\text { of GDP) }\end{array}$ & (percent) & $\begin{array}{c}\text { Change in shares to total } \\
\text { debt (percent) }\end{array}$ \\
\hline \hline UK (1946-80) & 85 & 35 & 6 & 7 & 21 & 6 \\
Japan (1946-64) & 98 & 19 & 11 & 42 & -33 & 40 \\
\hline
\end{tabular}

Sources: Abbas et al. (2014b) and authors' calculations.

The SFA again slowed debt reduction after World War II. But in contrast to the aftermath of World War I, when the negative contribution of the SFA was limited to France, after WWII a large contribution of the SFA was common across G-20 advanced economies. Nationalizations, subsidies for loss-making public enterprises and other below-the-line operations contributed to this negative SFA and thereby to increases in debt, partially offsetting the effects of primary surpluses and a favorable growth-interest-rate differential in this period of consolidation). ${ }^{89}$

Implications for Today. Countries have pursued two broad approaches to debt reduction. The orthodox approach relies on growth, primary surpluses, and the privatization of government assets. In turn this encourages long debt duration and non-resident holdings. Heterodox approaches, in contrast, include restructuring debt contracts, generating inflation, taxing wealth and repressing private finance. This in turn discourages foreigners from holding the government's obligations and investors from holding long-duration debt.

\footnotetext{
${ }^{89}$ The inflation and growth slowdown of the early 1970s may have added further to this effect, insofar as pressure for increased spending was accommodated but governments sought to hide it from voters and the bond market.
} 
Today, financial repression is unlikely to be as effective as after World War II. Repression then relied on tight financial regulation, capital controls, and limited investment opportunities. Today a much larger share of advanced economy debt is held by non-residents, and a lower share by banking systems, making it more difficult to maintain a captive investor base that accepts debt offering sub-market returns. In addition, regulatory measures compelling banks to hold domestic government debt and then attempting to inflate it away could threaten financial stability in the financially-competitive low-growth environment of the $21^{\text {st }}$ century. ${ }^{90}$

The value attached to price stability by central banks and retail investors in government bonds in turn limits the political viability of surprise inflation. Higher inflation would also have indirect costs, in the form of a persistent departure from less risky long-duration debt. Governments would be trading off lower short-run debt-servicing costs for higher costs and heightened volatility in the future. We saw this in the case of Japan in the previous subsection.

This tendency is similarly evident in Italy after 1970. Its experience shows that moving back to long-term debt denominated in domestic currency and with a fixed interest rate may take considerably longer than the time needed simply to bring down inflation. In the early 1970s, a spike in Italian inflation coincided with a sharp increase in the share of the Bank of Italy's holdings of sovereign debt, which peaked in 1976 (Figure 12). ${ }^{91}$ Unhappiness with inflation led in
Figure 12. Italy: Debt Composition in the 1970s through Euro Adoption

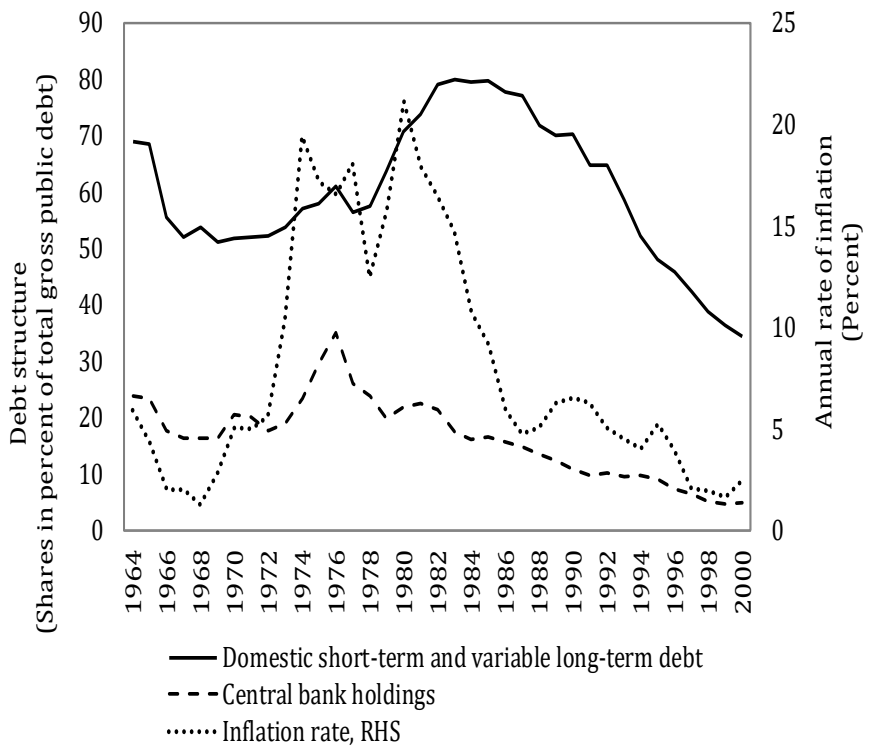

Source: Abbas et al. (2014b).

\footnotetext{
${ }^{90}$ Further, higher bank holdings of own sovereign debt can increase exposure to negative feedback loop between the sovereign and banks, as was demonstrated recently in the Euro Area sovereign debt crisis.

${ }^{91} \mathrm{~A}$ full discussion of Italian inflation in this period is beyond the ambit of this paper. Among other things, it would add the role of supply-side factors (the impact of the oil shock, the presence of wage indexation in the form of the Scala Mobile).
} 
1981 to the "divorce" between the government and the central bank. ${ }^{92}$ The Bank of Italy gained the autonomy to decide whether to purchase Treasury bills not taken up by brokers at auctions. The share of debt held by the central bank declined in the second half of the 1970s, but not until the 1980s did inflation come down. It took even longer for the combined share of domestic short-term debt and variable rate long-term debt to begin to fall.

Thus, not only would financial repression be difficult to implement under present circumstances, but its negative side-effects would persist.

\section{CONCLUSION}

For hundreds if not thousands of years, sovereigns have borrowed to secure borders to fight foreign military campaigns. The $19^{\text {th }}$ century was a transitional period when governments, while still borrowing to prosecute wars, issued debt to build roads, railways, and ports and to invest in education. The $20^{\text {th }}$ century then saw sharp increases in debt burdens as a result of major wars but also as a result of recessions, banking panics and financial crises, and of the public-policy responses to these events. The end of the last century also saw, for the first time, a secular increase in public-debt-to-GDP ratios in a variety of countries in conjunction not with wars and crises but in response to popular demands on governments for pensions, health care, and other often unfunded social services.

Debasement and restructuring also have a long history. In the $18^{\text {th }}$ and $19^{\text {th }}$ centuries, some governments went to extraordinary lengths to service and repay heavy debts incurred as a result of expensive wars (recall the examples of Britain, the U.S. and France in Section 4). Britain ran primary surpluses for the better part of a century, the United States for five decades. In part this reflected the political influence of creditors. It reflected the fact that the franchise was not yet universal and that contemporary perceptions of the role of government were different from today. It reflected the recognition by decision makers that the maintenance of debt-service payments, even when difficult, could deliver lower borrowing costs in normal times and aid with the mobilization of resources in the military and economic crises not infrequently faced by $18^{\text {th }}$ and $19^{\text {th }}$ century governments. Not least it reflected good

\footnotetext{
92 This was the equivalent of the Accord in the United States.
} 
luck - that Great Britain was not confronted with an equally costly war between 1815 and 1914 or the United States between 1865 and 1917, and that there was no economic slump as deep and long as the Great Depression of the 1930s (Grossman and Han 1993). Governments following this path found themselves able to issue debt at favorable interest rates, long maturities, and in their own currencies (Bordo, Meissner and Redish 2003).

Not all governments were able to implement this good equilibrium, however. Some countries defaulted and restructured their debts, often repeatedly. Inflation and financial repression were used to reduce domestic claims on the public sector. Episodes like that in the third quarter of the $20^{\text {th }}$ century, when high advanced economy debts were brought down through a combination of rapid economic growth and budgetary discipline, were exceptions to this rule.

We started with the observation that public debt is a Janus-faced asset class. History amply fleshes out this portrait. 


\section{DATA APPENDIX}

Countries underlying Table 1: Flow data include (28 countries): Argentina, Australia, Austria, Brazil, Canada, Chile, China, Colombia, Cuba, Denmark, France, Germany, Greece, Italy, Japan, Mexico, New Zealand, Norway, Peru, Portugal, Russia, Serbia, South Africa, Spain, Sweden, Turkey, Uruguay, U.S. Stock data cover (45 countries): Argentina, Australia, Austria, Belgium, Bolivia, Brazil, Bulgaria, Canada, Chile, China, Colombia, Croatia, Denmark, Dominican Republic, Ecuador, Egypt, El Salvador, Finland, France, Germany, Greece, Haiti, Honduras, Italy, Japan, Mexico, Netherlands, New Zealand, Nicaragua, Norway, Panama, Peru, Portugal, Romania, Russia, Spain, Sweden, Switzerland, Thailand, Turkey, U.K., U.S., Uruguay, Vietnam, and South Africa

Countries included in the analysis underlying Figure 1 (47 countries): Argentina, Australia, Austria, Belgium, Bolivia, Brazil, Canada, Chile, China, Colombia, Costa Rica, Denmark, Dominican Republic, Ecuador, Egypt, El Salvador, Finland, France, Germany, Greece, Guatemala, Honduras, Italy, Japan, Mexico, Morocco, Netherlands, New Zealand, Nicaragua, Norway, Panama, Paraguay, Peru, Portugal, Romania, Russia, South Africa, Spain, Sweden, Switzerland, Thailand, Tunisia, Turkey, U.K., U.S., Uruguay, and Vietnam.

Debt composition data: For advanced economies, data are drawn from Abbas et al. (2014b), and cover 8 G-20 advanced economies: Australia, Canada, France, Germany, Italy, Japan, the U.K. and the U.S. for the period 1900-2012. For emerging economies, data on debt composition by currency and maturity cover the period 1980-2012 and are drawn from Guscina and Jeanne (2006). They cover 8 G-20 emerging economies: Argentina, Brazil, China, India, Indonesia, Mexico, Russia, and Turkey.

Low-income countries analyzed in Sections 4-6 (57 countries): Based on IMF World Economic Outlook classification, countries considered include: Afghanistan, Bangladesh, Benin, Bhutan, Bolivia, Burkina Faso, Burundi, Cambodia, Cameroon, Central African Republic, Chad, Comoros, Democratic Republic of the Congo, Republic of Congo, Côte d'Ivoire, Djibouti, Eritrea, Ethiopia, The Gambia, Ghana, Guinea, Guinea-Bissau, Haiti, Honduras, Kenya, Kyrgyz Republic, Lao P.D.R., Lesotho, Liberia, Madagascar, Malawi, Mali, Mauritania, Moldova, Mongolia, Mozambique, Myanmar, Nepal, Nicaragua, Niger, Nigeria, Papua New Guinea, Rwanda, São Tomé e Príncipe, Senegal, Sierra Leone, Solomon Islands, Sudan, Tajikistan, Tanzania, Togo, Uganda, Uzbekistan, Vietnam, Yemen, Zambia, and Zimbabwe.

Countries that received debt relief under the HIPC initiative include (36 countries): Afghanistan, Benin, Bolivia, Burkina Faso, Burundi, Cameroon, Central African Republic, Chad, Comoros, Cote d'Ivoire, Democratic Republic of Congo, Ethiopia, The Gambia, Ghana, Guinea, Guinea-Bissau, Guyana, Haiti, Honduras, Liberia, Madagascar, Malawi, Mali, Mauritania, Mozambique, Nicaragua, Niger, Republic of Congo, Rwanda, São Tomé, Senegal, Sierra Leone, Tanzania, Togo, Uganda, and Zambia. The three “pre-decision” countries that are potentially eligible for HIPCs assistance are: Eritrea, Somalia, and Sudan. 


\section{REFERENCES}

Abbas, S. M. A., N. Belhocine, A. El-Ganainy, and M. Horton 2011. "Historical Patterns and Dynamics of Public Debt_Evidence from a New Database,” IMF Economic Review, Vol. 59, No. 4, pp. 717-742.

Abbas, S.M.A., N. Belhocine, A. El-Ganainy, and A. Weber 2014a. "Current Crisis in Historical Perspective,” in C. Cottarelli, P. Gerson, and A. Senhadji, editors, Post-Crisis Fiscal Policy, pp. 161-191 (Cambridge, MA: MIT Press).

Abbas, S. M. A., L. Blattner, M. De Broeck, A. El-Ganainy and M. Hu 2014b. “Sovereign Debt Composition in Advanced Economies: A Historical Perspective,” IMF Working Paper, No. 14/162 (September).

Acemoglu, D. 2005. "Politics and Economics in Weak and Strong States," Journal of Monetary Economics, 52(7): 1199-1226.

Accominotti, O., M. Flandreau, R. Rezzik and F. Zumer 2010. "Black Man's Burden, White Man's Welfare: Control, Devolution and Development in the British Empire, 1880-1914," European Review of Economic History 14(1): 47-70.

Alesina, A. and E. Spolaore 2003. The Size of Nations, Cambridge, Mass.: MIT Press.

Almunia, M., A. Benetrix, B. Eichengreen, K. O’Rourke and G. Rua 2010. "From Great Depression to Great Credit Crisis: Similarities, Differences and Lessons,” Economic Policy 25, pp.219-265.

Alt, J., D. Lassen and J. Wehner 2014. “It Isn't Just about Greece: Domestic Politics, Transparency and Fiscal Gimmickry in Europe,” British Journal of Political Science, 44, pp. 707-716

Andersson, F. and J. Lennard 2018. "Irish GDP between the Famine and the First World War: Estimates based on a Dynamic Factor Model,” European Review of Economic History forthcoming.

Aristotle 1920. Oeconomica, Oxford: Clarendon Press.

Ba, H. 2017. "The Systemic Causes of Financial Crises in the Long Nineteenth Century," Business and Politics, pp.1-17.

Barro, R. 1987. "Government Spending, Interest Rates, Prices, and Budget Deficits in the United Kingdom, 1701-1918”, Journal of Monetary Economics 20(2), pp. 221-47.

Bayoumi, T. and M. Bordo 1998. "Getting Pegged: Comparing the 1879 and 1925 Gold Resumptioiins,” Oxford Economic Papers 50(1), pp.122-149. 
Belforti, F. 1843. Storia della Città di Perugia, Perugia: Vincenzo Santucci.

Bent, P. and R. Esteves 2016. “Capital Pull Factors at the Turn of the $20^{\text {th }}$ Century: A Sectoral Analysis”, Mimeo.

Besley, T. and T. Persson 2009. "The Origins of State Capacity: Property Rights, Taxation and Ppolitics,” American Economic Review 99 (4). pp. 1218-1244.

Bordo, M. and J. Haubrich 2010. "Credit Crises, Money and Contractions: An Historical View," Journal of Monetary Economics 57, pp.1-18.

Bordo, M., C. Meissner and A. Redish 2003. "How Original Sin was Overcome: The Evolution of External Debt Denominated in Domestic Currencies in the United States and the British Dominions, 1800-2000,” NBER Working Paper No. 9841 (July).

Bordo, M. and A. Murshid 2001. "Are Financial Crises Becoming Increasingly More Contagious? What is the Historical Evidence on Contagion?” in S. Claessens and K. Forbes, editors, International Financial Contagion, pp.367-403 (Boston: Kluwer Academic).

Bordo, M. and H. Rockoff 1996. "The Gold Standard as a "Good Housekeeping Seal of Approval,” Journal of Economic History 56, pp.389-428.

Bordo, M. and E. White 1991. "A Tale of Two Currencies: British and French War Finance during the Napoleonic Wars,” Journal of Economic History 51, pp.303-316.

Brewer, J. 1989. The Sinews of Power. War, Money and the English State, 1688-1783, London: Unwin Hyman.

Broadberry, S., B. Campbell, A. Klein, B. van Leeuwen and M. Overton 2015. British Economic Growth 1270-1870, Cambridge: Cambridge University Press.

Brooks, R., K. Ross, R. Powell, Y. Quemarez, D. Ross, M. Cortes, S. Rizavi, B. Ketchekmen and F. Fornasari 1998. "External Debt Histories of Ten Low-Income Developing Countries: Lessons from Their Experience,” IMF, Working Paper No. 98/72 (May).

Brown, E. C. 1956. "Fiscal Policy in the 'Thirties: A Reappraisal," American Economic Review 46, pp.866-879.

Bulow, J. and K. Rogoff 1989. "Sovereign Debt: Is to Forgive to Forget?" American Economic Review 79, pp.43-50.

Campbell, T. 2004. "Sound Finance: Gladstone and British Government Finance, 1880-1895," unpublished Ph.D. dissertation, London School of Economics.

Carter, S., S Gartner, M. Haines, A. Olmstead, R. Sutch and G. Wright eds. 2006. Historical Statistics of the United States: Earliest Times to the Present, NY: Cambridge University Press. 
Chabot, B. and C. Kurz 2012. "British Investment Trusts: The Precursors of Modern Structured Finance,” Mimeo.

Chambers, D. and R. Esteves 2014. "The First Global Emerging Markets Investor: Foreign \& Colonial Investment Trust 1880-1913”, Explorations in Economic History 52, pp.1-21.

Cohen-Setton, J., J. Hausman and J. Wieland 2017. "Supply-Side Policies in the Great Depression: Evidence from France,” Journal of Money, Credit and Banking 49, pp.273-318.

Crafts, N. and K. Harley 1992. "Output Growth and the British Industrial Revolution: A Restatement of the Crafts-Harley View,” Economic History Review 45, pp.703-730.

Crouzet, F. 2003. "The Historiography of French Economic Growth in the Nineteenth Century”, Economic History Review 56(2), pp. 215-242.

Daseking, C. and R. Powell 1999. "From Toronto Terms to the HIPC Initiative: A Brief History of Debt Relief for Low-Income Countries,” IMF Working Paper, No. 99/142.

Daunton, M. 2001. Trusting Leviathan. The Politics of Taxation in Britain, 1799-1914, Cambridge: Cambridge University Press.

Davis, L. and R. Huttenback 1986. Mammon and the Pursuit of Empire. The Political Economy of British Imperialism, 1860-1912, Cambridge: Cambridge University Press.

De Broeck, M. and Guscina, A. 2011. "Government Debt Issuance in the Euro Area: The Impact of the Financial Crisis,” IMF Working Paper No. 11/21 (January).

De Luca, G. 2008. “Government Debt and Financial Markets: Exploring Pro-Cyclical Effects in Northern Italy during the Sixteenth and the Seventeenth Centuries," in

F. Caselli, ed., Government Debts and Financial Markets in Europe, London: Picketing and Chatto, pp. 45-66.

De Vries, J. and A. van der Woude 1997. The First Modern Economy: Success, Failure, and Perseverance of the Dutch Economy, 1500-1815, Cambridge: Cambridge University Press.

Diaz-Alejandro, C. 1984. "Latin America in the 1930s, in R. Thorpe (ed), Latin America in the 1930s, London: Macmillan.

Dincecco, M. 2009. "Fiscal Centralization, Limited Government, and Public Revenues in Europe, 1650-1913,” Journal of Economic History 69, pp.48-103.

----- 2010. "Fragmented Authority from Ancien Régime to Modernity: A Quantitative Analysis,” Journal of Institutional Economics 6, pp.305-328. 
----- 2011. From Warfare to Wealth: The Military Origins of Urban Prosperity in Europe, Cambridge: Cambridge University Press.

----- 2015. “The Rise of Effective States in Europe.” Journal of Economic History 75, pp. 901-918.

Drelichman, M. and H.-J. Voth 2014. Lending to the Borrower from Hell: Debt, Taxes, and Default in the Age of Philip II, Princeton: Princeton University Press.

Dyson, K. 2014. States, Debt and Power: 'Saints' and 'Sinners in European History and Integration, New York: Oxford University Press.

Easterly, W. 2002. "How Did Heavily Indebted Poor Countries Become Heavily Indebted? Reviewing Two Decades of Debt Relief,” World Development 30, pp. 1677-1696.

Edelstein, M. 1982. Overseas Investment in the Age of High Imperialism: The United Kingdom, 1850-1914, New York: Columbia University Press.

Edwards, S. 2018. American Default: The Untold Story of FDR, the Supreme Court, and the Battle over Gold, Princeton: Princeton University Press.

Eichengreen, B. 1982. “The Proximate Determinants of Domestic Investment in Victorian Britain,” Journal of Economic History 42, pp.87-95.

Eichengreen, B. 1996. "Institutions and Economic Growth: Europe since 1945," in N. Crafts and G. Toniolo eds., Economic Growth in Europe since 1945, Cambridge: Cambridge University Press.

Eichengreen, B. and P. Garber 1991. "Before the Accord: U.S. Monetary-Financial Policy 1945-51,” in G. Hubbard ed., Financial Markets and Financial Crises, pp.175-206 (Chicago: University of Chicago Press).

Eichengreen, B. and U. Panizza 2016. “A Surplus of Ambition: Can Europe Rely on Large Primary Surpluses to Solve its Debt Problem?” Economic Policy 31, pp.5-49.

Eichengreen, B. and R. Portes 1986, "Debt and Default in the 1930s: Causes and Consequences,” European Economic Review 30, pp.79-120.

Epstein, S. 2000. Freedom and Growth: The Rise of States and Markets in Europe, 1300-1750, London: Routledge.

Esteves, R. 2013. "The Bondholder, the Sovereign and the Banker: Sovereign Debt and Bondholders' Protection before 1914,” European Review of Economic History 17, pp.389-407.

Esteves, R. and C. Tunçer 2016. "Feeling the Blues: Moral Hazard and Debt Dilution in Eurobonds Before 1914," Journal of International Money and Finance 65: 46-68. 
European Central Bank 2015. "The Fiscal Impact of Financial Sector Support during the Crisis,” Economic Bulletin 6, pp. 74-87.

Feis, H. 1930. Europe, the World's Banker, 1870-1914. An Account of European Foreign Investment and the Connection of World Finance with Diplomacy before the War, New Haven: Council on Foreign Relations.

Feldstein, M. 2002. “Economic and Financial Crises in Emerging Market Economies: Overview of Prevention and Management,” NBER Working Paper No. 8837 (March).

Ferguson, N. 2006. "Political Risk and the International Bond Market Between the 1848 Revolution and The Outbreak of the First World War.” Economic History Review 59, pp. 70112.

Fishlow, A. 1985. "Lessons from the Past: Capital Markets During the 19th Century and the Interwar Period,” International Organization 39, pp.38-93.

Flandreau, M. 2013. "Sovereign States, Bondholders Committees, and the London Stock Exchange in the Nineteenth Century (1827-68): New Facts and Old Fictions,” Oxford Review of Economic Policy 29, pp.668-96.

Flandreau, M., J. Flores, N. Gaillard and S. Nieto-Parra 2010. "The End of Gatekeeping: Underwriters and the Quality of Sovereign Bond Markets, 1815-2007," NBER International Seminar on Macroeconomics 2009, pp. 53-92.

Flandreau, M. and N. Sussman 2005. "Old Sins: Exchange Clauses and European Foreign Lending in the $19^{\text {th }}$ Century," in B. Eichengreen, B. and R. Hausmann (eds.), Other People's Money. Debt Denomination and Financial Instability in Emerging Markets Economies, Chicago: University of Chicago Press, pp.154-189.

Flandreau, M. and F. Zumer 2004. Making of Global Finance, 1880-1913, Paris: OECD.

Flores, J. 2011. "Information Asymmetries and Conflict of Interest during the Baring Crisis, 1880-1890,” Financial History Review 18, pp.191-215.

Frederiksen, M. W. 1966. “Caesar, Cicero and the Problem of Debt”, Journal of Roman Studies 56, pp.128-41.

Gautam, M. 2003. "Debt Relief for the Poorest: An OED Review of the HIPC Initiative," Washington, D.C.: World Bank Publications.

Greene, J. 1989. “The External Debt Problem of Sub-Saharan Africa,” IMF Staff Papers 36, pp. 836-874.

Grossman, H. and T. Han 1993. “A Theory of War Finance,” Defence Economics 4, pp.33-44 
Guinnane, T. 2004. "Financial Vergangenheitsbewaeltigung: The 1953 London Debt Agreement,” Economic Growth Center Discussion Paper 880, Department of Economics, Yale University.

Guscina, A. and Jeanne, O. 2006. "Government Debt in Emerging Market Countries: A New Data Set,” IMF Working Paper No. 06/98 (April).

Ho, C.-Y. and D. Li 2010. “A Mirror of History: Chinese Bond Market from 1921 to 1942,” unpublished manuscript, Georgia Institute of Technology and Fudan University (July).

Hozier, H. ed 1872. The Franco-Prussian War: Its Causes, Incidents and Consequences, London: William Mackenzie.

International Monetary Fund (IMF) 2013. "Reassessing the Role and Modalities of Fiscal Policy in Advanced Economies,” IMF Policy Paper, September 2013.

Krumm, K. 1985. “The External Debt of Sub-Saharan Africa: Origins, Magnitude and Implications for Action,” World Bank Staff Working Paper No. 741 (August).

Landes, D. 1958. Bankers and Pashas; International Finance and Economic Imperialism in Egypt, Cambridge, Mass: Harvard University Press.

League of Nations 1934. Commercial Banks, Geneva: League of Nations.

Lindert. P. 1994. “The Rise of Social Spending, 1880-1930," Explorations in Economic History 22: 1-34.

Lindert, P.H., Morton, P.J., 1989. “How sovereign debt worked” In: Sachs, J. (ed.), Developing Country Debt and Economic Performance, Chicago: University of Chicago Press, Chicago, pp. 39-106.

Lipson, C. 1985. Standing Guard: Protecting Foreign Capital in the Nineteenth and Twentieth Centuries, Berkeley: University of California Press.

MacDonald, J. 2003. A Free Nation Deep in Debt: The Financial Roots of Democracy, New York: Farrar, Straus and Giroux.

Maddison, A. 1995. Monitoring the World Economy 1820-1992, Paris: OECD Development Centre.

Maloney, J. 1998. “Gladstone and Sound Victorian Finance” in Maloney, J., ed. Debt and Deficits. An Historical Perspective, Cheltenham: Edward Elgar, pp.154-189. 
Maurer, H. and P. Grussenmeyer 2015. "Financial Assistance Measures in the Euro Area from 2008 to 2013: Statistical Framework and Fiscal Impact,” Statistics Paper Series No. 7, Frankfurt: European Central Bank.

Mauro, P., N. Sussman and Y. Yafeh 2002. "Emerging Market Spreads: Then Versus Now," Quarterly Journal of Economics, 117: 695-733.

Mauro, P. and J. Zilinsky 2016. "Reducing Government Debt Ratios in an Era of Low Growth,” Peterson Institute for International Economics, Policy Brief 16-10 (July).

Meyer, R. 1970. Bankers' Diplomacy: Monetary Stabilization in the Twenties, New York: Columbia University Press.

Michie, R. 1987. The London and New York Stock Exchanges 1850-1914, London: Unwin Hyman Ltd.

----- 1999. The London Stock Exchange: A History, Oxford: Oxford University Press.

----- 2006. The Global Securities Market. A History, Oxford: Oxford University Press.

Middleton, R. 1984. "The Measurement and Influence of Fiscal Policy in Britain in the 1930s," Economic History Review 37, pp.103-106.

Mitchener, K. and M. Weidenmier 2008. "The Baring Crisis and the Great Latin American Meltdown of the 1890s," Journal of Economic History 68, pp.462-500.

----- 2010. “Supersanctions and Sovereign Debt Repayment,” Journal of International Money and Finance 29, pp.19-36.

----- 2015. "Was the Classical Gold Standard Credible on The Periphery? Evidence from Currency Risk,” Journal of Economic History 75, pp.479-511.

Munro, J. 2013. "Rentes and the European' Financial Revolution"', in G. Caprio ed., Handbook of Key Global Financial Markets, Institutions, and Infrastructure, vol. I, Oxford: Elsevier, pp. 235-249.

Neal, L. 1990. The Rise of Financial Capitalism. International Capital Markets in the Age of Reason, Cambridge: Cambridge University Press.

----- 2015. A Concise History of International Finance: From Babylon to Bernanke, Cambridge: Cambridge University Press.

Neal, L. and M. Weidenmier 2003. "Crises in the Global Economy from Tulips to Today: Contagion and Consequences” in M. Bordo, A. Taylor and J. Williamson (eds.), Globalization in Historical Perspective, Chicago: University of Chicago Press. 
North, D. and B. Weingast 1989. "Constitutions and Commitment: Evolution of the Institutions Governing Public Choice in Seventeenth-Century England”, Journal of Economic History 49, pp.803-832.

Obstfeld, M. and A. Taylor (2004) Global Capital Markets: Integration, Crisis, and Growth, Cambridge: Cambridge University Press.

Padgett, J. 2012. “Early Capitalism and State Formation,” in J. Padgett and W. Powell, eds., The Emergence of Organizations and Markets. Princeton, NJ: Princeton University Press.

Pezzolo, L. 2014. “The Via Italiana to Capitalism” in L. Neal and J. Williamson, eds., The Cambridge History of Capitalism, Vol. 1, Cambridge: Cambridge University Press.

Platt, D. C. M. 1968. Finance, Trade, and Politics in British Foreign Policy 1815-1914, Oxford: Oxford University Press.

Pollack, S. 2014. “The First National Income Tax, 1861-1872,” Tax Lawyer 67, pp.1-20.

Reinhart, C., Reinhart, V. and C. Trebesch 2016. "Global Cycles: Capital Flows, Commodities, and Sovereign Defaults, 1815-2015,” NBER Working Paper No. 21958.

Reinhart, C. and K. Rogoff 2009. This Time is Different. Eight Centuries of Financial Folly, Princeton: Princeton University Press.

----- 2011. “The Forgotten History of Domestic Debt,” The Economic Journal, Vol. 121, No. 52, pp. 319-350.

Reinhart, C. and B. Sbrancia 2015. “The Liquidation of Government Debt,” IMF Working Paper No. 15/7 (January).

Reinhart, C. and C. Trebesch 2014. “A Distant Mirror of Debt, Default, and Relief,” NBER Working Paper No. 20577 (October).

Ritschl, A. 2013. "Reparations, Deficits and Debt Default: The Great Depression in Germany," in: N. Crafts and P. Fearon, eds., The Great Depression of the 1930s: Lessons for today, Oxford : Oxford University Press, pp. 110-139.

Roberds, W. and F. Velde. 2014. “Early Public Banks” FRB of Chicago Working Paper No. 2014-03.

Romer, C. 1992. “What Ended the Great Depression?” Journal of Economic History 52, pp. 757-784.

Scheffers, S. and R. Roberts 2014. The Media and Financial Crises: Comparative and Historical Perspectives, London: Routledge. 
Stasavage, D. 2011 States of Credit: Size, Power, and the Development of European Polities, Princeton: Princeton University Press.

Suter, C. 1990. Schuldenzyklen in der Dritten Welt: Kreditaufnahme, Zahlungskrisen und Schulden-regelungen peripherer Länder im Weltsystem von 1820 bis 1986, Frankfurt/ Main: A. Hain.

Thomas, B., 1934, “Germany,” in H. Dalton et al., Unbalanced Budgets. A Study of the Financial Crisis in Fifteen Countries, London: Routledge.

Tilly, C. 1992. Coercion, Capital, and European States AD 990-1992, New York: WileyBlackwell.

Tomita, T. 2005. “Japanese Government Bonds 100 Years Ago,” Nomura Research Institute Paper No.90 (June).

Tomz, M. and M. L. J. Wright 2013. "Empirical Research on Sovereign Debt and Default.” Annual Review of Economics 5, pp. 247-272.

Tracy, J. 1985. A Financial Revolution in the Habsburg Netherlands: 'Renten' and 'Renteniers' in the County of Holland, 1515-1565, Berkeley: University of California Press.

Tunçer, C. 2015. Sovereign Debt and International Financial Control. The Middle East and the Balkans, 1870-1914, Houndmills: Palgrave Macmillan.

Twomey, M. 1983. “The 1930s Depression in Latin America: A Macro Analysis,” Explorations in Economic History 20, pp.221-247.

United Nations 1946. Public Debt 1914-1946, New York: United Nations.

Weber, A. 2012. "Stock-Flow Adjustments and Fiscal Transparency: A Cross-Country Comparison,” IMF Working Paper, No. 12/49 (January).

World Bank 2005. “Lessons and Controversies from Financial Crises in the 1990s,” Country Notes for Chapter 7: Financial Liberalization: What Went Right, What Went Wrong?” in Economic Growth in the 1990s: Learning from a Decade of Reform, Washington, D.C.: World Bank.

Yared, P. 2018. "Rising Government Debt and What to Do About It,” NBER Working Paper No. 24979 (August).

Yun-Casalilla, B. and P. O’Brien, eds. 2015. The Rise of Fiscal States. A Global History 15001914, Cambridge: Cambridge University Press. 